\title{
Comparison of the U.S. Lead Recycling Industry in 1998 and 2011
}

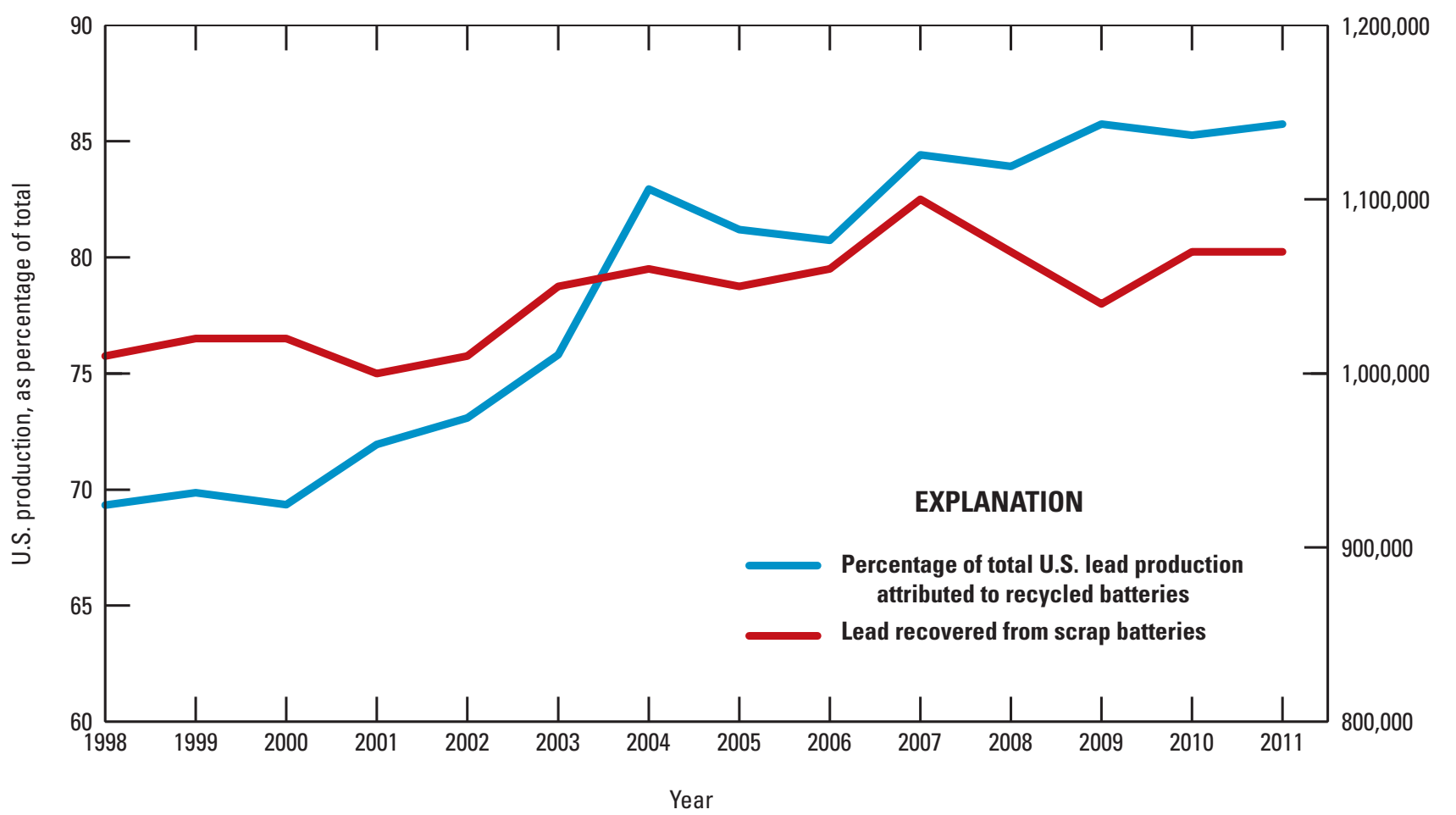

Scientific Investigations Report 2014-5086 
Cover image. Graph showing percentage of total U.S. lead production attributed to recycled batteries (figure 4 in report). 


\section{Comparison of the U.S. Lead Recycling Industry in 1998 and 2011}

By David R. Wilburn

Scientific Investigations Report 2014-5086 


\title{
U.S. Department of the Interior SALLY JEWELL, Secretary
}

\section{U.S. Geological Survey \\ Suzette M. Kimball, Acting Director}

\author{
U.S. Geological Survey, Reston, Virginia: 2014
}

For more information on the USGS - the Federal source for science about the Earth, its natural and living resources, natural hazards, and the environment, visit http://www.usgs.gov or call 1-888-ASK-USGS.

For an overview of USGS information products, including maps, imagery, and publications, visit http://www.usgs.gov/pubprod

To order this and other USGS information products, visit http://store.usgs.gov

Any use of trade, firm, or product names is for descriptive purposes only and does not imply endorsement by the U.S. Government.

Although this information product, for the most part, is in the public domain, it also may contain copyrighted materials as noted in the text. Permission to reproduce copyrighted items must be secured from the copyright owner.

Suggested citation:

Wilburn, D.R., 2014, Comparison of the U.S. lead recycling industry in 1998 and 2011:

U.S. Geological Survey Scientific Investigations Report 2014-5086, 20 p., http://dx.doi.org/10.3133/sir20145086.

ISSN 2328-0328 (online) 


\section{Contents}

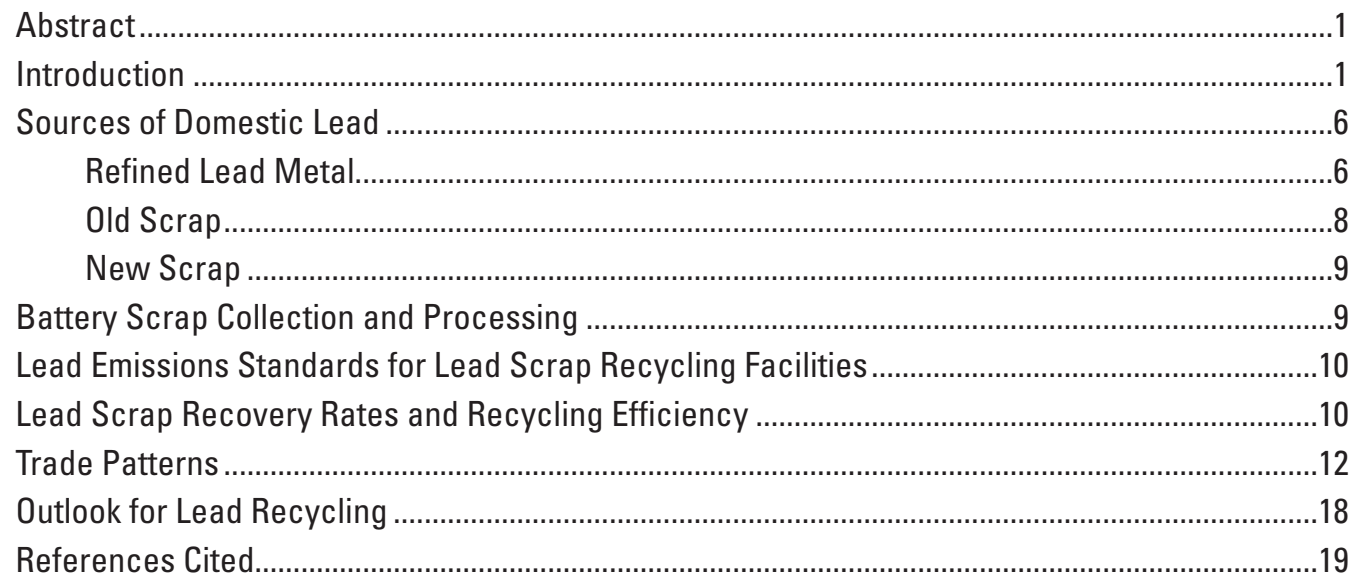

\section{Figures}

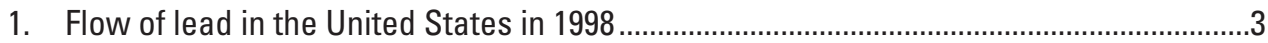

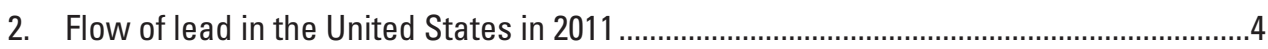

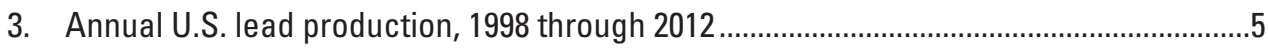

4. Percentage of total U.S. lead production attributed to recycled batteries ........................5

5. U.S. lead consumption by end use, expressed in metric tons and as a percentage of the total U.S. apparent consumption of lead, 1998 through 2011 .................................7

6. Lead recovered from scrap recycled in the United States, 1998 through 2011 ................8

7. Lead content of battery imports and battery exports, by category, 1998

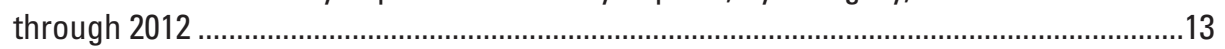

8. Imports of lead contained in lead scrap and used lead-acid batteries to the United States from selected countries or regions, 1998 through 2012 ...........................14

9. Exports of lead contained in lead scrap and used lead-acid batteries to the United States from selected countries or regions, 1998 through 2012 ............................14

10. Contribution of Mexico and Canada in terms of percentage of lead contained in imported lead scrap and lead-acid batteries, 2000 through 2012..................................16

11. Contribution of Mexico and Canada in terms of percentage of lead contained in exported new and used lead-acid batteries and lead scrap, 2000 through 2012

\section{Table}

1. Lead recycling rates and selected measures of efficiency....... 


\section{Conversion Factors}

\begin{tabular}{lcl}
\hline \multicolumn{1}{c}{ Multiply } & By & \multicolumn{1}{c}{ To obtain } \\
\hline cubic meter & 35.31 & cubic foot $\left(\mathrm{ft}^{3}\right)$ \\
pound, avoirdupois $(\mathrm{lb})$ & 0.4536 & kilogram $(\mathrm{kg})$ \\
gram $(\mathrm{g})$ & 0.03527 & ounce, avoirdupois $(\mathrm{oz})$ \\
milligram $(\mathrm{mg})$ & 1,000 & gram $(\mathrm{g})$ \\
microgram $(\mu \mathrm{g})$ & 1,000 & milligram $(\mathrm{mg})$ \\
kilogram $(\mathrm{kg})$ & 2.205 & pound avoirdupois $(\mathrm{lb})$ \\
metric ton $(\mathrm{t})$ & 1.102 & ton, short $(2,000 \mathrm{lb})$ \\
metric ton per year $(\mathrm{t} / \mathrm{yr})$ & 1.102 & ton, short, per year $(\mathrm{ton} / \mathrm{yr})$ \\
\hline
\end{tabular}

\section{Abbreviations}

$\begin{array}{ll}\text { BCI } & \text { Battery Council International } \\ \text { CEC } & \text { Commission for Environmental Cooperation } \\ \text { EPA } & \text { U.S. Environmental Protection Agency } \\ \text { ISRI } & \text { Institute of Scrap Recycling Industries } \\ \mathrm{Mt} & \text { million metric tons } \\ \mathrm{Mt} / \mathrm{yr} & \text { million metric tons per year } \\ \text { NAAOS } & \text { National Ambient Air Quality Standard } \\ \text { SLAB } & \text { spent lead-acid battery } \\ \text { SLI } & \text { starting-lighting-ignition [type of battery] } \\ \text { USGS } & \text { U.S. Geological Survey } \\ \text { USITC } & \text { U.S. International Trade Commission }\end{array}$




\title{
Comparison of the U.S. Lead Recycling Industry in 1998 and 2011
}

\author{
By David R. Wilburn
}

\section{Abstract}

Since 1998, the structure of the lead recycling industry has changed and trade patterns of the domestic lead recycling industry have shifted. Although the domestic demand for lead has remained relatively constant since 1998, production of lead has increasingly shifted to the domestic secondary lead industry. The last primary lead smelter in the United States closed at the end of 2013, at which time the secondary lead industry became the sole source of domestic lead production. The amount of lead recovered annually from scrap batteries generally increased from about 900,000 metric tons in 1995 to more than 1,100,000 metric tons in 2012. The percentage of total U.S. lead production attributed to battery scrap increased from 65 percent in 1995 to 87 percent in 2012 .

Since the North American Free Trade Agreement took effect in 1994, trade patterns among the United States, Canada, and Mexico have changed for recycled lead products. In the late 1990s, the principal sources of lead waste and scrap not derived from batteries were Canada, Mexico, and South America; by 2011, the principal sources were Central America and Asia, with decreasing amounts from Canada and South America. Since 1998, the amount of lead derived from imported batteries and scrap from Canada has ranged from 50 to 90 percent, and the amount imported from Mexico has ranged from 3 to 20 percent. Canada received about 50 percent of the lead contained in spent lead-acid batteries and scrap exported from the United States in 1998, and Mexico received about 4 percent. By 2012, however, the amount of lead scrap exported to Canada had decreased to about 10 percent, and the amount of lead-based scrap products, primarily batteries, exported to Mexico from the United States had increased to 47 percent. Vertical integration of the domestic secondary lead industry and higher costs required to implement more stringent ambient air standards in the United States have led some companies to shift lead recycling operations to Mexico. U.S. secondary lead producers are increasingly competing with Canadian and Mexican facilities for market share.

\section{Introduction}

Although cumulative lead production and consumption in the United States has not varied significantly over the past decade, the structure and amount of lead-acid battery recycling has changed as a result of changes in battery demand and types, consolidation of the secondary battery industry, improvements in collection and distribution procedures for used batteries, increased environmental regulation, upgrades in battery scrap processing and lead smelting technology, and variation in the composition of lead alloys. Also, the pattern of imports and exports of recycled lead materials has shifted noticeably. A previous review of lead recycling in the United States by the U.S. Geological Survey (USGS) was published in 2004 and reported data as of 1998 (Smith, 2004). The current report updates domestic lead recycling information from 1998 to 2011, incorporating recycling and trade information on lead-acid batteries and electronic scrap, and evaluates potentially significant sources of lead supply or actions that may affect lead supply in the near future. Information for 2012 was used where publically available. The report describes changes that have taken place in the industry since 1998 and discusses issues of interest to policymakers and the industry. Consumption and trade data on lead-acid batteries were developed by using a methodology similar to that reported by Wilburn and Buckingham (2006).

The United States was the second leading producer of refined lead in the world in 2011 after China, producing about 11 percent of the world's refined lead from its secondary lead refining industry. Secondary lead, derived primarily from recycled lead-acid batteries, accounted for 91 percent of U.S. refined lead production. Scrap lead is also recovered from dross, dust, residue, and sludge generated by smelting of metals; lead pipe and sheet; printing materials; sheaths from power and telephone cable; and vehicle wheel weights. Because of its corrosion resistance, lead scrap is available for recycling decades after it is produced. In light of changing supply and use patterns and recent revisions in the air toxics standards for secondary lead smelters that became effective January 5, 2012 (U.S Environmental Protection Agency, 2012a), an understanding of the current sources of consumption, production, and supply of secondary (recycled) lead and 
the changes in demand and supply of this material in recent years is essential to assessing industry economics and future sources of availability/supply.

Smith (2004) describes the history and use of lead prior to 1998; this information will not be repeated in this report. Figures 1 and 2 provide data on the flows associated with domestic supply of primary and secondary lead and the patterns of lead use in 1998 and 2011. The sources and distribution of lead supply have been quantified to allow for the estimation of scrap recycling efficiency and scrap recycling rates for the two timeframes. Trends in production and consumption since 1998 are reported in figures 3 through 11. A discussion of these trends is useful for understanding the differences in lead flow reported in figures 1 and 2. Production and consumption data have been extracted from parts of the USGS Minerals Yearbook series published between 1999 and 2013.

Figure 3 shows annual U.S. production of refined lead from primary sources and secondary metal recovered from scrap for the period 1998 through 2012. Since 1998, domestic primary lead production has decreased about 67 percent, whereas domestic secondary lead production has remained stable or increased slightly (about 4 percent).

Strong demand for lead in China and other emerging economies has influenced the price of lead and scrap lead, particularly since 2001 . The increasing reliance on the secondary lead industry of the United States, which accounted for 91 percent of U.S. refined lead production in 2011, meant that the price and availability of lead scrap has become an increasingly important component affecting the domestic lead price, and possibly global lead prices. Domestic secondary refineries frequently competed with foreign producers for scrap. According to the International Lead and Zinc Study Group, refined lead consumption in China increased 734 percent from 1998 to 2010 (U.S. Geological Survey, 2013a, p. 82). The reported North American Producer price of lead in 1998 was $\$ 0.453$ per pound and the average price of lead in 2012 was $\$ 1.22$ per pound, an increase of 159 percent since 1998. The constant dollar price of lead increased 79 percent from 1998 to 2012, when expressed in terms of the Consumer Price Index with a base year of 1998 (Guberman, 2013; U.S. Geological Survey, 2013a, p. 82).

In 1998, primary lead was processed at three facilities in Missouri (Mo.) and Montana (Mont.). In 2001, ASARCO Incorporated suspended operations indefinitely at its East Helena, Mont., lead smelter, with an estimated refined lead capacity ranging from 60,000 to 75,000 metric tons per year (t/yr). In 2003, Doe Run suspended production at its Glover, Mo., facility with an estimated capacity of 110,000-125,000 t/yr of refined lead, in response to a declining domestic market. In 2008, Doe Run closed one of its two furnaces at the Herculaneum, Mo., facility, reducing capacity from about $227,000 \mathrm{t} / \mathrm{yr}$ of refined lead to about $120,000 \mathrm{t} / \mathrm{yr}$. The remaining furnace closed at the end of 2013. Doe Run had agreed to close Herculaneum as part of a settlement agreement with the U.S. Environmental Protection Agency (EPA), the State of Missouri, and the U.S. Department of Justice and had not announced plans to replace the facility at that time (Environment News Service, 2010). With the closing of the Herculaneum primary lead smelter-refinery at the end of 2013, the secondary lead industry is the sole domestic source of refined lead.

The percentage of total domestic lead production derived from secondary sources has increased from about 77 percent in 1998 to about 91 percent in 2012. The increase reflects primary lead plant closures and restructuring of the secondary lead industry owing to increased costs of environmental regulation. In 1998, 20 companies produced secondary lead; 9 companies operating 17 plants produced 98 percent of the recycled lead (Smith, 1999b), and 13 smaller plants with capacities less than 10,000 metric tons $(t)$ accounted for about 2 percent of recycled lead production (Smith, 1999a). By 2011, 12 companies produced secondary lead; 7 companies operating 14 plants produced the majority of recycled lead (Guberman, 2013). At the same time that some of the smaller recyclers have ceased production, capacities at some of the larger facilities have been increased, and a new plant has begun production. The total primary lead capacity has decreased and the total secondary lead capacity has increased since 1998.

Since 2009, the U.S. secondary lead industry's capacity has contracted with the closure of Exide Technologies' $80,000-\mathrm{t} / \mathrm{yr}$ Baton Rouge, Louisiana, facility in that year, the 2012 closure of its 65,000-t/yr facility in Frisco, Texas, and the 2013 closure of its 70,000-t/yr facility in Reading, Pennsylvania. However, these closures have been offset by the 2010 expansion of EnviroFocus Technologies' facility in Tampa, Florida, to 100,000 t/yr and the 2012 opening of Johnson Controls' 120,000-t/yr secondary lead facility in Florence, South Carolina, resulting in an overall expansion of domestic secondary lead capacity. Exide Technologies suspended operations at its facility in Vernon, California, in 2013 while investigating production options after the California Department of Toxic Substances Control reported the facility was not meeting State environmental standards (Recycling Today, 2013). The cumulative production capacity of the U.S. secondary lead industry by the end of 2013 is expected to be about 1.2 million metric tons of lead per year (Mt/yr), about the same as its capacity in 1998 and slightly less than the combined production from the primary and secondary lead industry in the United States in 2011 of $1.25 \mathrm{Mt} / \mathrm{yr}$ of lead (Guberman, 2013).

In 1998, battery scrap accounted for about 69 percent of U.S. lead production. By 2011, battery scrap accounted for about 86 percent of U.S. lead production (or about 95 percent of all lead recovered from recycled sources) (Guberman, 2013). Figure 4 shows the increasing significance of recycled batteries on total U.S. lead production. The percentage attributed to the recycling of lead-acid batteries is expected to grow in the short term as domestic primary lead production is curtailed and as battery scrap production from new secondary production facilities replaces output from older production facilities. 


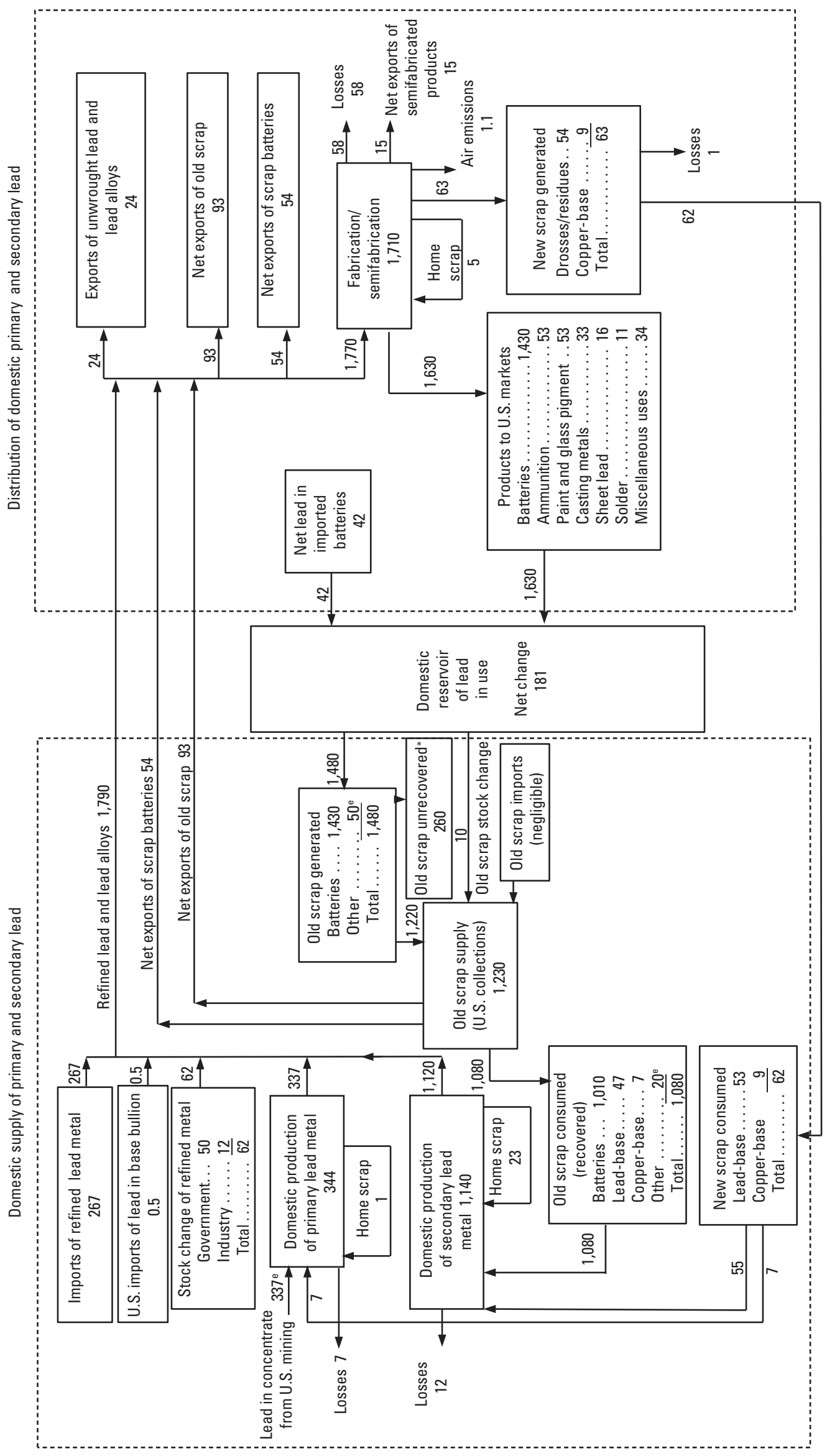

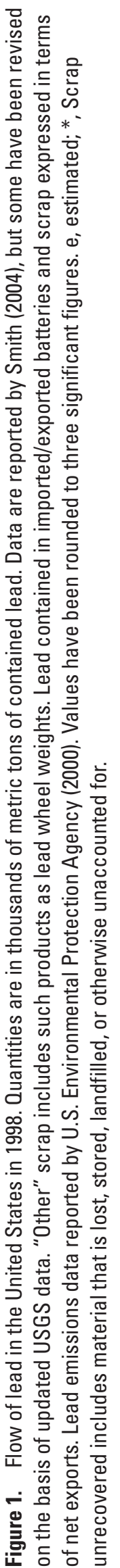




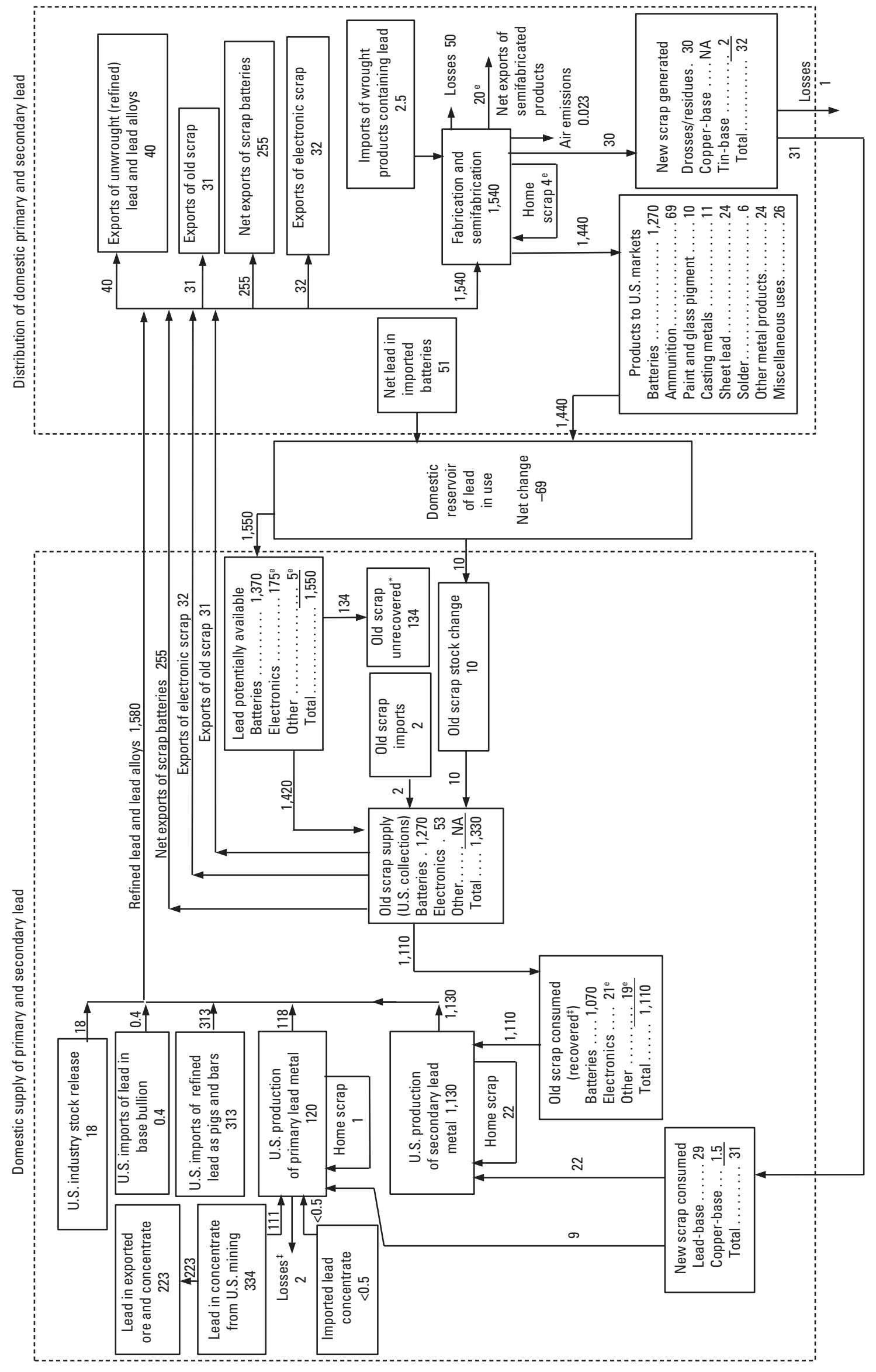

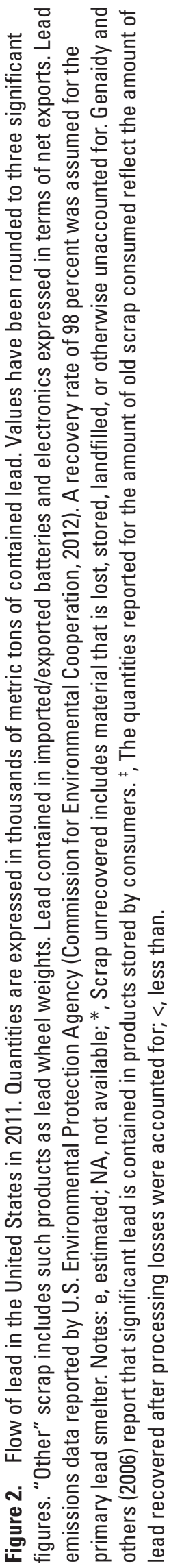




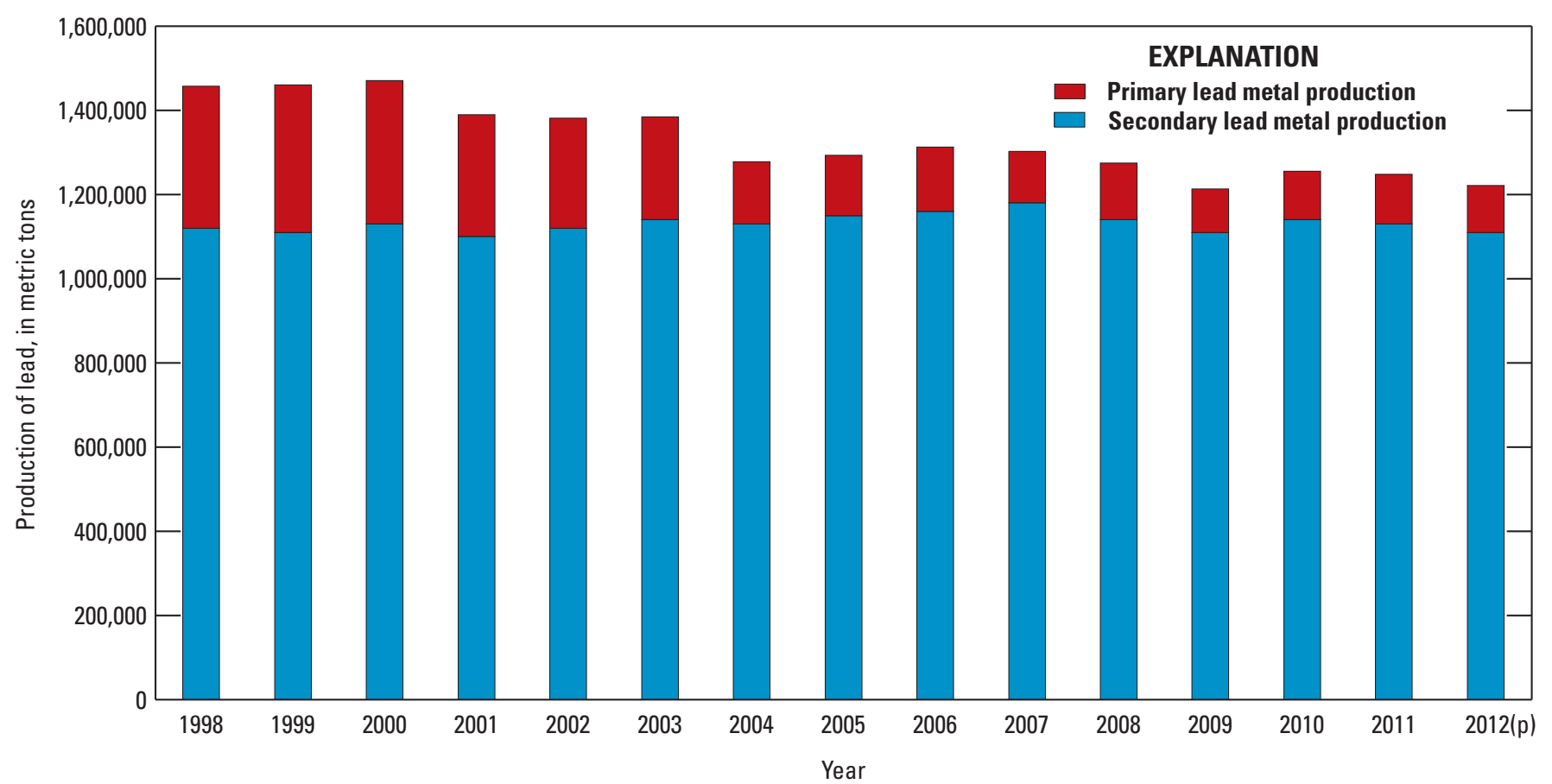

Figure 3. Annual U.S. lead production, 1998 through 2012. This graph shows the amount of lead produced from the primary smelters and lead recovered from recycled materials, primarily batteries, at secondary smelters. Data are from U.S. Geological Survey Minerals Yearbook series, 1999-2013, and U.S. Geological Survey Mineral Commodity Summaries 2013. (p), preliminary.

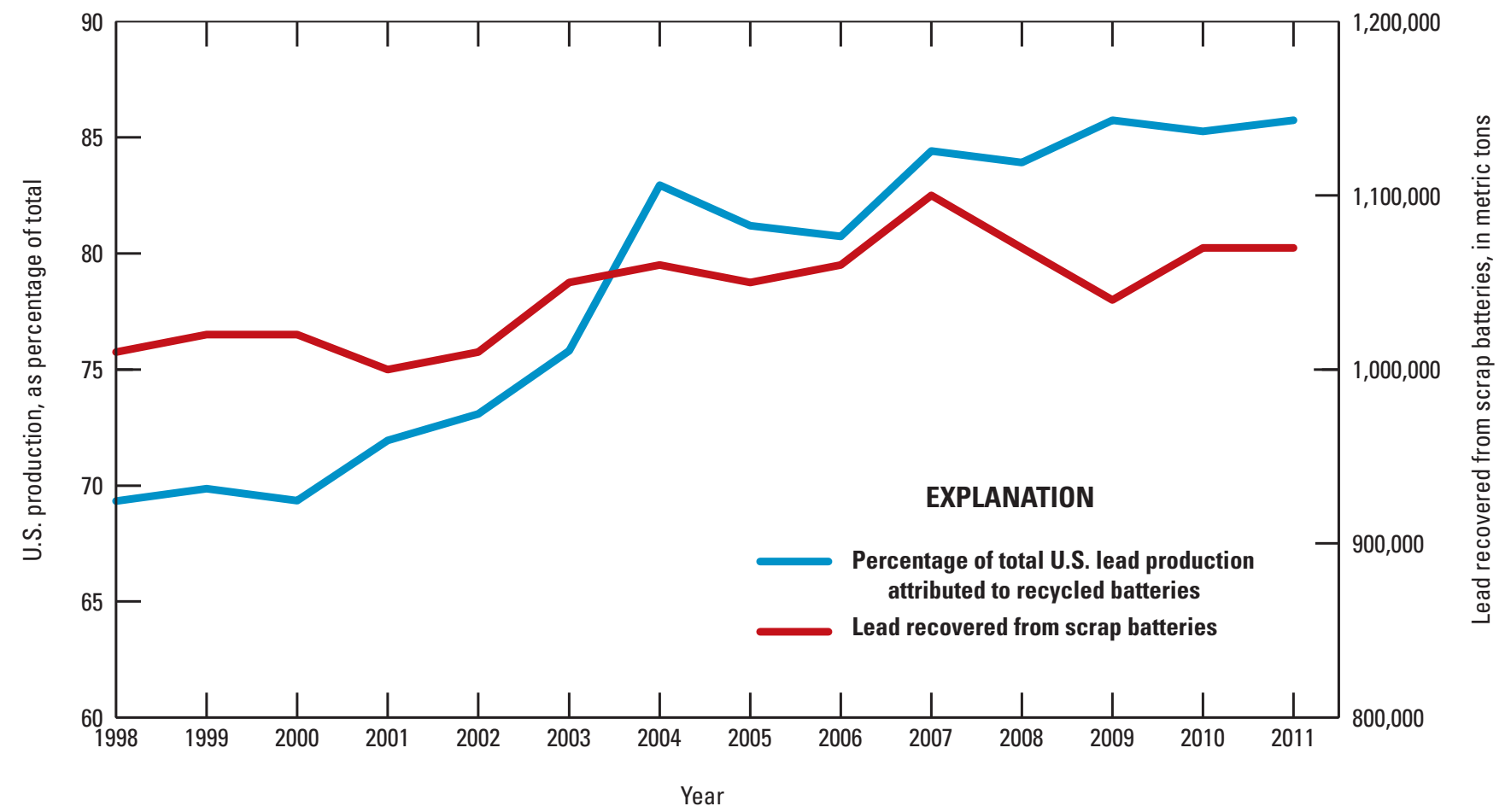

Figure 4. Percentage of total U.S. lead production attributed to recycled batteries. Johnson Controls opened its Florence, South Carolina, secondary lead recycling plant in 2012, so the percentage for 2012 is expected to be higher than that reported for 2011. Data are from U.S. Geological Survey Minerals Yearbook series, 1999-2012. 
Figure 5 shows U.S. lead consumption by principal end use for the period 1998 through 2011, expressed as a percentage of total U.S. apparent consumption. Except for 2002 and 2003, when lead-acid battery production decreased as the result of the closure of several U.S. secondary lead facilities, lead use in batteries has exceeded 86 percent of U.S. consumption. Lead used in ammunition has increased from about 3 percent of U.S. consumption in 1998 to about 5 percent in 2011, owing to Government purchases, stockpiling in response to pending gun control legislation, the rise in popularity of sport shooting, and increasing security concerns. The use of lead in sheet applications (primarily for radiation shielding) increased slightly from 1998 through 2002, and consumption has remained essentially stable since 2003. Use of lead in paint and glass pigment has decreased from about 3.3 percent of U.S. consumption in 1998 to about 0.7 percent in 2011 as a result of stringent regulation of lead-based paints and decreasing use of lead-coated cathode ray tubes in electronics. Lead use in cast metals, such as lead wheel weights and fishing weights, has decreased about 66 percent since 1998, as concern over the environmental effects of using lead-based products is debated and as some State and local municipalities have begun regulating use of such products. A more detailed discussion of the stocks and flows of lead-based wheel weights in the United States has been published by Bleiwas (2006). Lead has also been used in solder (including electronic components) and in brass and bronze alloys. Use of lead in these applications has remained relatively stable; the percentage of U.S. consumption ranges from 0.4 to 0.8 percent for solder and from 0.1 to 0.2 percent for brass and bronze (U.S. Geological Survey, 1999-2013).

Although most of the scrap consumed in the United States is derived as old scrap from recycled batteries, electronics, or other reclaimed products, a small amount of new scrap is derived from manufacturing and refining facilities. Figure 2 shows estimates of the amount of scrap generated and recovered in 2011, and figure 6 shows the annual consumption of old and new scrap in the United States from 1998 through 2011 (Guberman, 2013). As demand for lead-based products such as electronics, paint, and lead wheel weights has decreased in the United States, primary lead production has decreased, and the contribution from new lead scrap generated by the U.S. manufacturing sector also has decreased. In 2003, one of two primary lead smelters in the United States closed, and secondary lead scrap recycling increased from 2003 through 2007 in response to an increasing lead price. Because of the economic downturn that took place in 2008 and 2009, there was a global surplus of refined lead and prices declined, leading to a decrease in domestic lead recycling (U.S. Geological Survey, 2013). Since 2009, the lead price has stabilized, as has lead scrap recycling.

\section{Sources of Domestic Lead}

The supply of primary and secondary refined lead for the United States is made up of domestic primary and secondary refinery production; net imports of refined lead, lead scrap, and lead contained in products; and sales of metal from Government and industry stocks. The U.S. Government sold the remaining inventory of lead stored in its National Defense Stockpile by December 2006. Since 1998, the mix of primary and secondary lead production has shifted in favor of secondary production. Figures 1 and 2 summarize the principal sources and distribution of the supply of primary and secondary (recycled) lead and quantify the flow of lead in the United States in 1998 and 2011, respectively. The original data reported by Smith (2004) used in figure 1 excludes statistics on lead contained in batteries, battery scrap, or electronic scrap, but data on batteries and battery scrap have been incorporated into the 1998 and 2011 flow assessments reported in figures 1 and 2, and estimates for electronic scrap have been included in the 2011 flow assessment as shown in figure 2. Data on trade were compiled and estimated from the annual USGS Minerals Yearbook reports and from data reported by the U.S. International Trade Commission (USITC).

\section{Refined Lead Metal}

Figures 1 and 2 suggest that, in terms of refined lead metal, only minor changes in the industry have taken place since 1998. Domestic production of lead in 1998 consisted of 337,000 t of primary metal and 1,120,000 $\mathrm{t}$ of secondary metal, compared to $118,000 \mathrm{t}$ of primary metal and $1,130,000 \mathrm{t}$ of secondary metal in 2011. In 1998, 267,000 t of refined lead metal was imported, 24,000 t of unwrought lead metal and lead alloys was exported, and approximately $15,000 \mathrm{t}$ of lead in semifabricated products was exported. In 2011, 313,000 t of refined lead was imported, 40,000 t of unwrought lead metal and lead alloys was exported and approximately 20,000 $\mathrm{t}$ of lead in semifabricated products was exported. In 1998, changes in stocks accounted for $62,000 \mathrm{t}$ of lead supply, primarily from releases from Government stocks; in 2011, only 18,000 t of lead was released from industry stocks.

By specification, refined lead must contain at least 99.9 percent lead, and the most widely used specification for refined lead imposes limits on a number of trace metals contained in the lead. The major difference between primary lead and secondary lead is the amount of trace metals, primarily antimony, arsenic, bismuth, copper, nickel, selenium, silver, tellurium, tin, and zinc found in the lead. Primary lead companies generally produce 99.99 percent lead, whereas secondary lead production facilities do not remove all of the trace metals in the refining process, so that the specification for secondary lead is 99.97 percent lead. Refined lead used in batteries requires low levels of antimony, arsenic, nickel, and tellurium-elements that reduce decomposition of the electrolyte and production of gas upon charging. 


\section{A. U.S. consumption of lead in batteries}

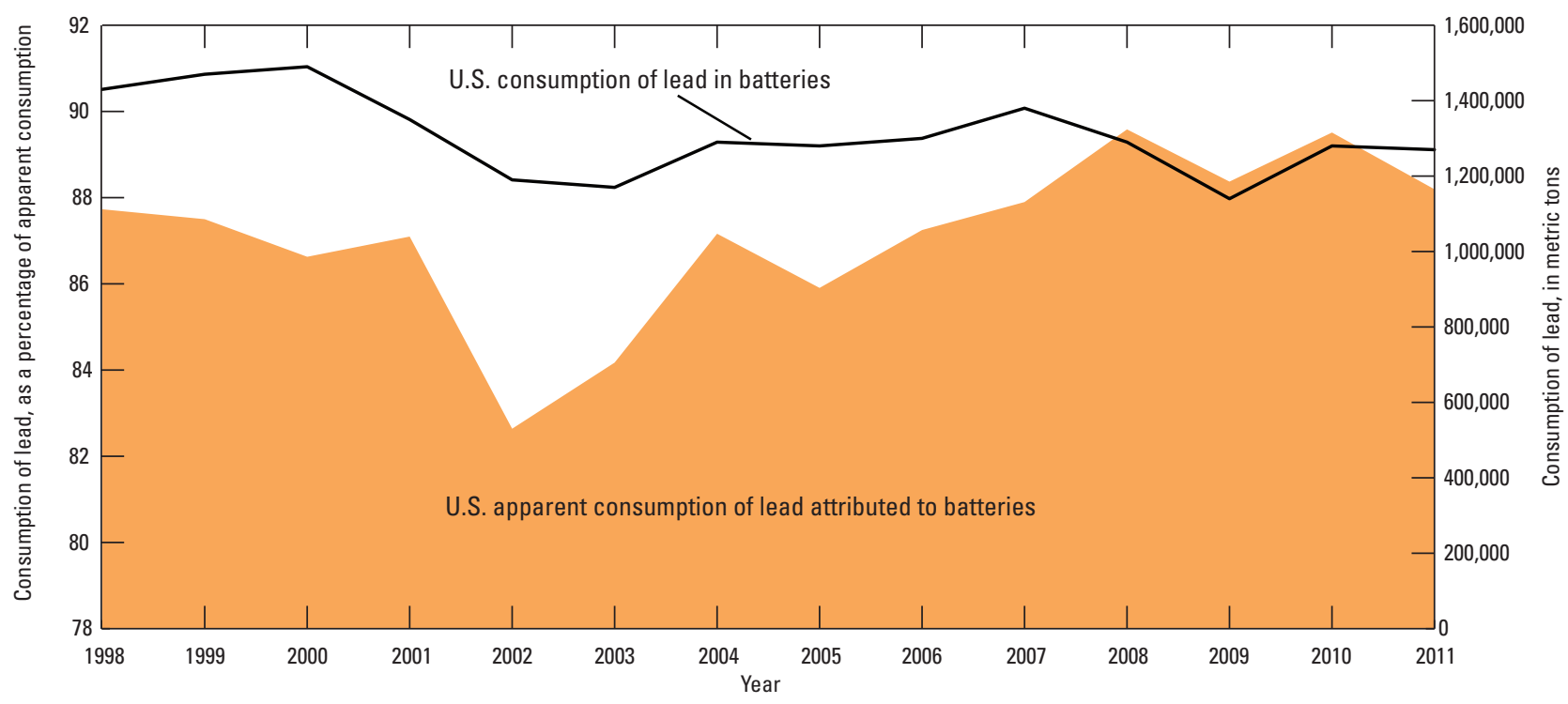

B. U.S. consumption of lead in nonbattery uses

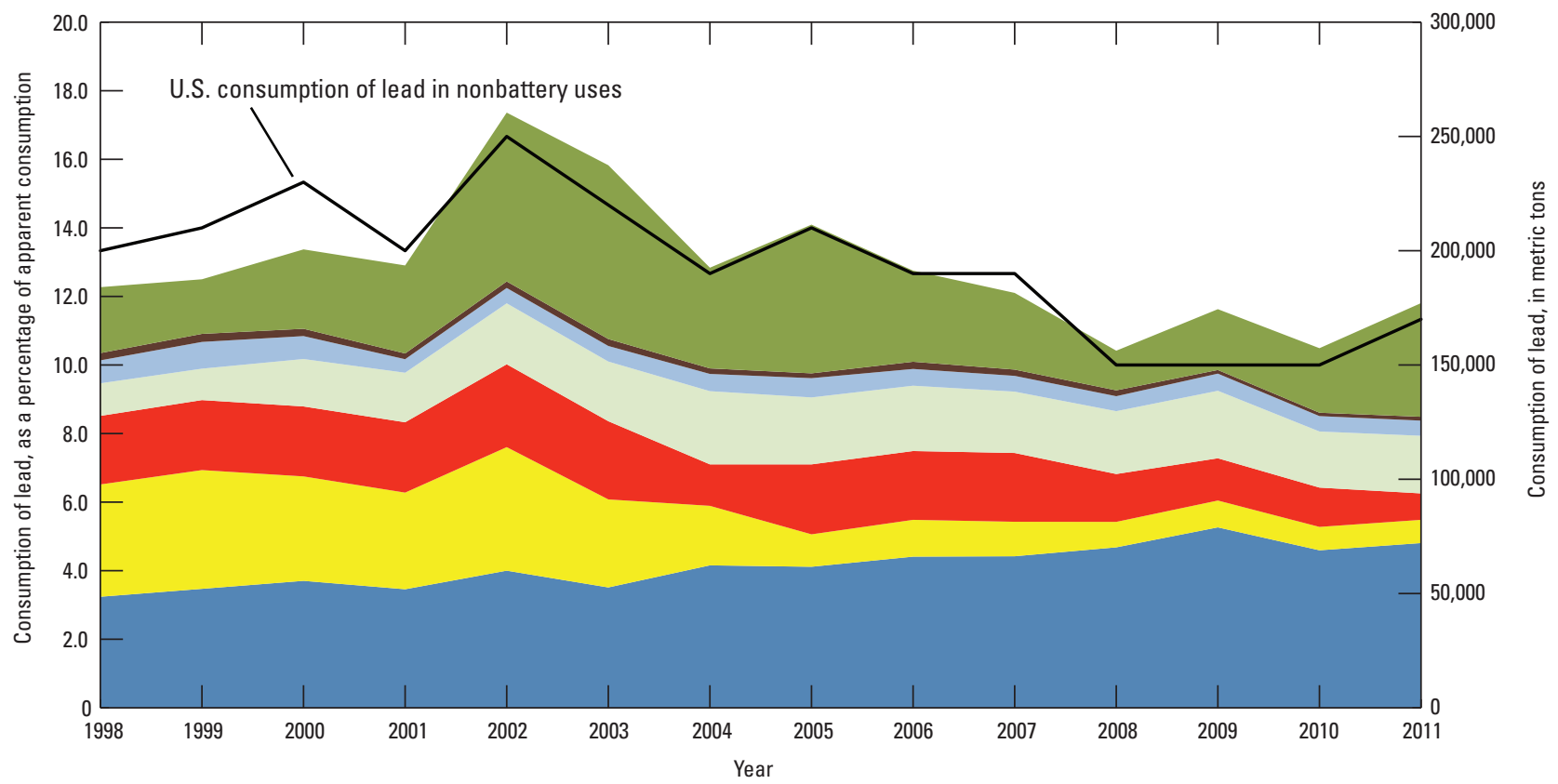

EXPLANATION

U.S. consumption of lead, as percentage of apparent consumption

\begin{tabular}{l}
$\square$ Batteries \\
$\square$ Other nonbattery uses \\
Brass and bronze \\
$\square$ Solder, including electronic components \\
\hline$\square$ Sheet lead \\
$\square$ Cast metals \\
$\square$ Paint and glass pigment \\
$\square$ Ammunition
\end{tabular}

Figure 5. U.S. lead consumption by end use, expressed in metric tons and as a percentage of the total U.S. apparent consumption of lead, 1998 through 2011. Data are from U.S. Geological Survey Minerals Yearbook series, 1999-2013. 


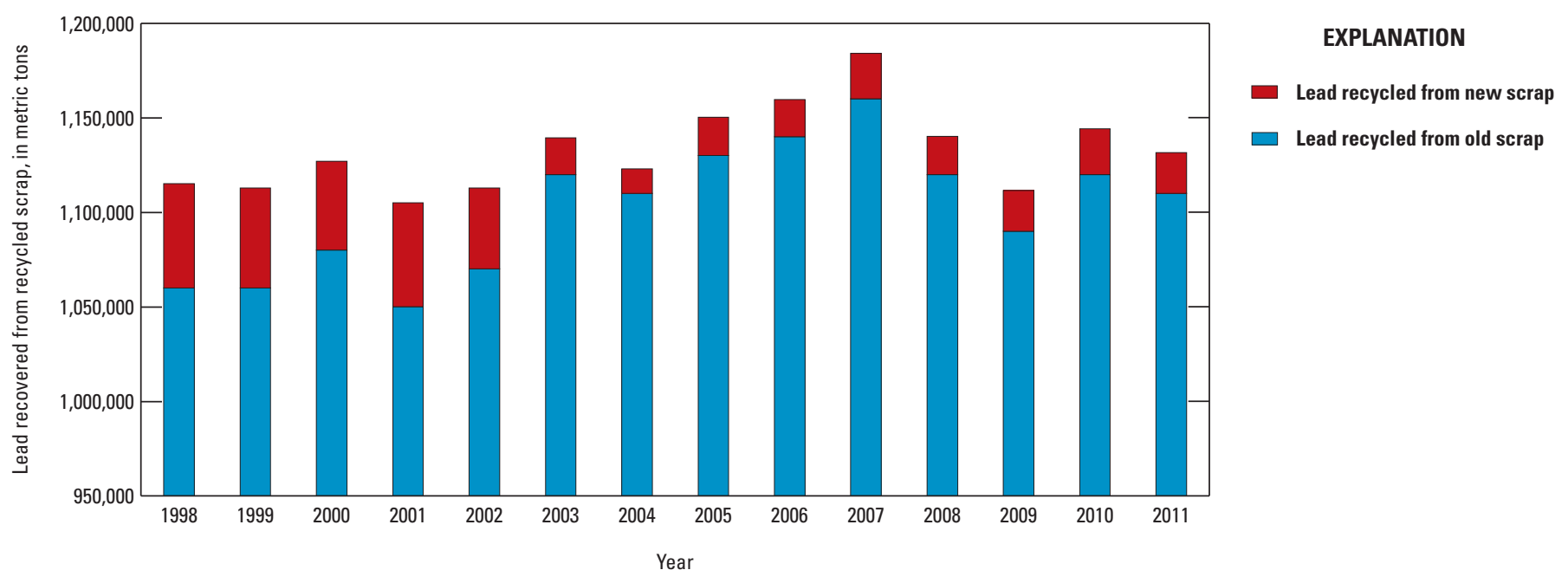

Figure 6. Lead recovered from scrap recycled in the United States, 1998 through 2011. New scrap is derived from the manufacturing process, including metal and alloy production. Old scrap is derived from the recycling of consumer products. Data are from Papp (2013).

\section{Old Scrap}

Changes can be seen when the data from these figures are viewed in terms of the amount of lead scrap generated. Although the U.S. Government does not consider lead-acid batteries to be hazardous waste, Federal law requires, with certain exceptions, used batteries containing lead to be treated as Universal Waste (40 CFR Part 273). The Universal Waste Rule issued by EPA in 1995 prohibits handlers from disposing of waste lead-containing batteries in landfills and required that these batteries be sent for recycling. In addition, 44 States have some type of regulation governing the manner of disposal or recycling of lead-acid batteries (Battery Council International, 2013). State laws incentivize the recycling of batteries by banning the disposal of lead-acid batteries in a landfill; establishing a deposit system for new battery sales; requiring retailers, wholesalers, and manufacturers to take back batteries; or making it a violation to send spent lead-acid batteries to unlicensed recycling facilities in the United States. EPA data suggest that about 96 percent of all automotive leadacid batteries are recycled in the United States (U.S. Environmental Protection Agency, 2013). Non-automotive batteries, commonly used to power industrial equipment, emergency lighting, and alarm systems, use the same collection process as automotive batteries. The Rechargeable Battery Recycling Corporation, a nonprofit public service organization established in 1996, collects and recycles small sealed lead batteries as part of its recycling stream.

The largest source of material for the lead recycling industry is the recycling of spent lead-acid batteries. In 1998, approximately 88 percent of these spent batteries were of the starting-lighting-ignition (SLI) automotive type, with an average life of about 4 years; 8 percent were of the motive type, with an average life of 6 years, and were used to propel an electric vehicle such as a forklift or golf cart; and 4 percent were of the stationary type, with a 10-year life, and were used to provide standby power for large emergency lighting, security, telecommunication, and uninterruptible power systems (Battery Council International, 1998). The estimate for the amount of old scrap generated in 1998 was derived from Smith (2004) and based on lead consumed in the manufacture of SLI batteries in 1994, motive power batteries in 1992, and stationary batteries in 1988. Approximately 96 percent of the old scrap generated came from spent lead-acid batteries. The remainder came from other sources such as castings, sheet metal, solders, and miscellaneous fabricated parts.

Data reported by Smith (2004) as updated for this study suggest that the old scrap supply in 1998 included 1,430,000 $\mathrm{t}$ of lead generated from batteries, 50,000 $t$ of lead from other sources of scrap, and 10,000 t of lead from changes in stocks. Approximately 88 percent of the battery lead generated came from SLI batteries, approximately 8 percent came from motive batteries, and about 4 percent came from stationary batteries (Battery Council International, 2003). Of this 1998 old scrap supply, approximately 1,080,000 t of lead was recycled, 260,000 t of lead was landfilled, lost, stored, or otherwise unrecovered, and most of the rest was accounted for by net exports (the United States exported 93,000 t of lead scrap and $54,000 \mathrm{t}$ of lead contained in spent lead-acid batteries more than it imported). The Institute of Scrap Recycling Industries, Inc. (ISRI) reports that about 108,000 $t$ of old scrap was exported in 2001 (Institute of Scrap Recycling Industries, Inc., 2012).

By 2011, the amount of lead contained in collected scrap batteries in the United States changed little from the $1.43 \mathrm{Mt}$ reported for 1998 to about 1.37 Mt. Approximately 79 percent of the lead generated came from SLI batteries, 12 percent came from motive batteries, and 9 percent came from 
stationary batteries (Battery Council International, 2012). The amount of lead contained in shipments of SLI batteries increased by approximately 272,000 t (6 percent) from 1998 to 2011, whereas the amount of lead contained in shipments of motive batteries increased by about 139,000 t (31 percent) and the amount of lead contained in shipments of stationary batteries increased 561,000 $t$ (249 percent). The amount of lead used in stationary batteries accounted for the largest increase in old scrap generation from 1998 to 2011, with uncertainties in power availability and rising power costs stimulating demand for backup power systems. Rising demand for hybrid-electric and electric vehicles since 2011 will likely increase the future contribution of lead from batteries used in these types of vehicles; however, improvements in battery technologies are likely to extend battery lives beyond the $4-10$ years assumed in this study.

Recovery of lead scrap generated from electronic devices was not considered in the 1998 data; however, it has been reported in the 2011 analysis shown in figure 2. On the basis of data reported by the EPA, an estimated 175,000 $t$ of lead contained in electronic scrap was potentially available for recycling in 2011 and an estimated 53,000 $t$ of lead was contained in electronic products collected for recycling (U.S. Environmental Protection Agency, 2011a). It is possible that a significant amount of the lead contained in electronic scrap is found in the leaded glass used in computer monitors and television screens. Because this source of lead is difficult to separate and is not often recovered, the collection and subsequent lead recovery rate for recycled electronics is low, varying from about 40 percent for computers to 11 percent for mobile devices (U.S. Environmental Protection Agency, 2011a). It is estimated that approximately 61 percent of all electronic scrap waste collected in the United States for recycling is exported (Occupational Knowledge International, 2011), suggesting that approximately $32,000 \mathrm{t}$ of lead contained in electronic scrap was exported in 2011 and approximately 21,000 t of lead contained in electronic scrap was recycled in the United States. USGS data suggest that approximately $40,000 \mathrm{t}$ of lead was contained in nonbattery scrap recovered in the United States in 2011. If 21,000 t of lead was recovered from electronic scrap in 2011, then approximately 19,000 t of lead was contained in scrap recovered from other materials such as scrap metal, ammunition, and lead wheel weights. These values are reflected in figure 2.

Data compiled for this study suggest that the lead potentially available for recycling in 2011 included $1.37 \mathrm{Mt}$ of lead generated from batteries, $175,000 \mathrm{t}$ of lead contained in electronic scrap, 10,000 t of lead from changes in stocks, and approximately $5,000 \mathrm{t}$ of lead that was available from other sources of scrap. Of this material, approximately $1.33 \mathrm{Mt}$ of lead was collected for recycling, 31,000 $\mathrm{t}$ of old scrap was exported, and 134,000 $t$ was landfilled, lost, stored, unaccounted for, or otherwise unrecovered. In addition, net exports of lead contained in lead-acid batteries amounted to approximately 255,000 t; exports of lead in electronic scrap amounted to about 32,000 t. The 2011 amount for old scrap that was lost, unrecovered, unaccounted for, or landfilled is still significant because it is thought to include material that has been stored by consumers for future use or future recycling (Genaidy and others, 2008). The estimate of the amount of old scrap generated in 2011 was based on lead consumed in the manufacture of SLI batteries in 2007, motive power batteries in 2005, and stationary batteries in 2001. ISRI reports that about 31,000 t of lead scrap was exported in 2011 (Institute of Scrap Recycling Industries, Inc., 2012).

\section{New Scrap}

The quantity of refined lead recovered from new scrap produced during refining and manufacturing was estimated from the gross weight of purchased dross and residues reported to the USGS as a source of scrap by the lead recycling industries. The 1998 data (fig. 1) included lead from lead-based drosses and residues and from copper-based alloys (Smith, 1999a); the 2011 data (fig. 2) included lead from leadbased drosses and residues, copper-based alloys, and tin-based alloys (Guberman, 2013). Battery manufacturers recover essentially all of the lead scrap generated in battery production, mostly from grid and post trimmings. The recovery rate for both primary and secondary lead was assumed to be 98 percent. New scrap is collected and remelted for reuse in the fabrication process.

\section{Battery Scrap Collection and Processing}

Most States and some local jurisdictions have implemented procedures for recycling spent lead-acid batteries. Retailers accumulate these spent batteries in exchange when customers purchase new batteries. Battery manufacturers typically collect spent batteries from retailers when delivering shipments of new lead-acid batteries, then recover the lead content of the spent batteries through tolling agreements with secondary lead smelters. Recovered lead is returned to the manufacturer as feedstock for the production of new batteries. If the manufacturer owns the secondary smelter, the tolling step is eliminated. Batteries that are not recycled are collected by scrap dealers. These dealers typically collect from sources other than large retailers, such as junkyards, service stations, and small retailers, and they subsequently export the spent batteries or sell the spent batteries on the open market. The amount of material collected by scrap dealers is not well documented.

Processing of spent batteries begins by draining the battery acid, dismantling the battery and separating the components, and then processing each component to recover reusable materials. The lead-containing components recovered from the battery consist of lead alloy from the grids and posts, lead oxides from the electrode paste, and other lead compounds 
generated from the battery cell reactions. Data compiled by the Battery Council International (BCI) suggest that lead accounts for 58.6 percent of the total weight of a typical undrained battery for a passenger car or light commercial vehicle, or 73.6 percent of the total weight of a drained battery designed for a similar use (Battery Council International, 2005). The average lead weight for this type of vehicle battery for 2007-11 was estimated by BCI to be 9.8 kilograms (21.7 pounds), slightly greater than the 9.7 kilograms (21.4 pounds) used in the 1997-2001 recycling study. BCI assumed that batteries sent to Canada or Mexico were exported undrained and that batteries exported to other countries were drained prior to export (Battery Council International, 2003, 2012).

Lead-bearing battery paste is desulfurized then often combined with the lead-bearing battery grids and posts as feed to a reverberatory furnace. Output from this furnace yields a raw lead product and a slag containing 20 to 40 percent lead. Slag is further processed in a blast or electric-reduction furnace to recover additional lead. The raw lead from these furnaces is melted to remove additional impurities, adjusted to customer specifications, and then cast into ingots for shipment.

In 1998, secondary lead scrap produced approximately 60 percent soft lead, 37 percent antimonial lead, and about 3 percent lead of other compositions. In 2011, approximately 85 percent of the secondary lead scrap was produced in the form of soft lead, and the remaining 15 percent was in the form of antimonial lead. Lead used in storage batteries produced in the United States in 2011 consumed about 65 percent soft lead and about 27 percent antimonial lead (Guberman, 2013). With increasing use of low-maintenance and maintenance-free batteries, the consumption of antimonial lead in batteries has decreased.

\section{Lead Emissions Standards for Lead Scrap Recycling Facilities}

The EPA issued environmental regulations for lead processing facilities in June 1997 to establish limits for hazardous air pollutants from agglomerating furnaces, dryers, fugitive dust sources, refining kettles, and smelting furnaces (U.S. Environmental Protection Agency, 1997). The EPA reported total lead emissions of $570 \mathrm{t}$ from the primary lead smelting industry, $460 \mathrm{t}$ from the secondary lead smelting industry, and $110 \mathrm{t}$ from lead battery manufacturing in 1998 (U.S. Environmental Protection Agency, 2000).

The EPA reduced the National Ambient Air Quality Standard (NAAQS) for lead from 1.5 micrograms per cubic meter $\left(\mu \mathrm{g} / \mathrm{m}^{3}\right)$ to $0.15 \mu \mathrm{g} / \mathrm{m}^{3}$ in 2008 (Schmidt, 2010). On December 16, 2011, the EPA updated the air toxic standards for secondary lead smelters, lowering the stack lead emission limits from 2.0 milligrams per dry standard cubic meter $(\mathrm{mg} / \mathrm{dscm})$ for any individual stack to a facility wide, flowweighted average emission limit of $0.20 \mathrm{mg} / \mathrm{dscm}$ with a limit of $1.0 \mathrm{mg} / \mathrm{dscm}$ applicable to any individual stack (U.S.
Environmental Protection Agency, 2012a). The EPA estimated that the 2011 lead emissions from 9 of the 15 evaluated U.S. facilities producing in 2011 would likely result in ambient lead concentrations above the current NAAQS for lead of $0.15 \mu \mathrm{g} / \mathrm{m}^{3}$, mainly owing to excessive fugitive dust emissions (U.S. Environmental Protection Agency, 2011b).

The domestic lead recycling industry has significantly reduced the level of lead emissions since 1998. Total lead emissions attributed to the primary lead industry amounted to $570 \mathrm{t}$ in 1998 and $54 \mathrm{t}$ in 2005, the most recent figure reported from the National Emissions Inventory by the EPA. The tenfold reduction in lead emissions from 1998 to 2005 was likely the result of stricter regulatory controls, modernization of facilities using improved technology, and the closure of the Glover, Mo., production facility. In 2010, the domestic secondary lead industry had reduced the level of lead emissions to $23 \mathrm{t}$, a 95 -percent reduction from the $460 \mathrm{t}$ reported for 1998 and a 56-percent reduction from the $52 \mathrm{t}$ reported for 2007 (Commission for Environmental Cooperation, 2012).

The North American Free Trade Agreement between Canada, Mexico, and the United States requires that all member nations meet compatible human health standards. In Canada and the United States, increasingly stringent environmental regulations have led to steady improvement in technology, resulting in a reduction in lead emissions; however, these changes have not taken place to the same extent in Mexico (Commission for Environmental Cooperation, 2012). Newer facilities managed by U.S. companies such as Johnson Controls likely use technology capable of meeting or exceeding the more stringent U.S. environmental control standards. However, many secondary lead processing facilities in Mexico are small, with an annual capacity less than $30,000 \mathrm{t}$; consequently, they often lack the necessary capital to implement emission-control technology that is necessary for the facility to meet the more stringent emissions standards.

\section{Lead Scrap Recovery Rates and Recycling Efficiency}

Table 1 reports estimates of lead scrap recovery rates and measures of recycling efficiency for 1998 and 2011. The lead recycling industry supplied about $1,120,000 \mathrm{t}$ (or 69 percent) of U.S. lead consumption in 1998 and about 1,130,000 $\mathrm{t}$ (or 78 percent) of U.S. lead consumption in 2011. Nearly all of this was recovered from old scrap derived from batteries and, more recently, electronic products. The increase in percentage attributed to secondary lead is primarily the result of a decrease in primary lead production. Because most States have implemented procedures or policies to encourage lead-acid battery recycling, the recycling rate for lead-acid batteries has been reported to be about 97 percent for the 1997-2001 period and almost 99 percent for the 2007-11 period (Battery Council International, 2012), rates higher than those reported for some other countries (Genaidy and others, 2008). 
Table 1. Lead recycling rates and selected measures of efficiency.

\begin{tabular}{lccc}
\hline \multicolumn{1}{c}{ Measure } & $\begin{array}{c}\text { 1998 estimate } \\
\text { (percent) }\end{array}$ & $\begin{array}{c}\text { 2011 estimate } \\
\text { (percent) }\end{array}$ & Source of information \\
\hline Contribution of U.S. secondary lead consumption & 69 & 78 & USGS Minerals Yearbook 2011, 2013 \\
U.S. lead-acid battery recycling rate & 97 & 99 & Battery Council International, 2012 \\
U.S. lead recycling rate & 64 & 86 & Smith, 2004; This study, 2014 \\
U.S. lead recycling efficiency & 95 & 77 & Smith, 2004; This study, 2014
\end{tabular}

Estimates of recycling efficiency were developed for this study by using a methodology similar to that used by Smith (2004). Recycling efficiency reflects the relationship between what is theoretically available for the recycling of old postconsumer scrap and what is reported to be recovered. By definition, the recycling efficiency is a ratio computed by dividing the sum of old scrap consumed and old scrap exported by the sum of old scrap generated, old scrap imported, and any old scrap stock changes, measured in weight and expressed as a percentage. All components reflect estimates of the amount of lead contained in the component. Smith (2004) reported an estimate of about 95 percent for 1998 for lead-acid-battery recycling efficiency. The domestic proportion of the lead recycling efficiency estimate for 2011 was calculated to be about 77 percent. This value is lower than the 1998 value because (1) the amount of batteries available for recycling has increased faster than the amount being recycled and (2) a greater number of scrap batteries generated in the United States are being recycled in Mexico and are not included in the domestic estimate of recycling efficiency.

Another term that is commonly used as a measure of the amount of material being recycled is the recycling rate, which Smith (2004) defines as the fraction of the apparent supply of lead that is provided by recycled lead scrap, computed as the consumption of old plus new scrap divided by the apparent supply and expressed as a percentage. Apparent supply is defined as production of metal and recycled material plus net imports plus stock changes calculated on a contained weight of lead basis (Papp, 2013).

A number of models have been developed to estimate lead-acid-battery recycling rates in the United States using 2006 data, and the recycling rate estimates ranged from 66 percent to 74 percent (Genaidy and others, 2008). Recycling rate differences can be attributed to differences in data sources, definitions used for recycling calculations, and the material being evaluated. For example, BCI estimates a 2007-11 recycling rate for batteries of 98.7 percent by applying a ratio of the amount of scrapped lead recycled to the amount of lead available for recycling. This study developed estimates of the domestic lead recycling rate as defined above, based the estimates on USGS production and consumption data, USITC trade data for lead-based batteries and battery scrap, and estimates for electronic scrap generation and recycling developed by the EPA. An estimate of 64 percent lead recycling rate for all sources of lead (not just batteries) was calculated for 1998, and an estimate of 86 percent was calculated for 2011. The USGS reported a 81 percent recycling rate for batteries in 2010 and 73 percent lead recycling rate for 2011 (Papp, 2013), and the recycling rate for lead contained in electronic scrap in 2010 based on data reported by the EPA was estimated at 31 percent (Occupational Knowledge International, 2011). The USGS value for 2010 is lower than that estimated for this study because it only considers lead scrap recovered from consumer products in the United States and does not consider lead in recycled electronics or exported waste batteries intended for recycling. These battery recycling rate values are lower than those reported by BCI because the BCI statistics may include Johnson Controls recycled lead production in Mexico in their shipment statistics. BCI reports that Johnson Controls has redirected used batteries that historically would have been processed within the United States to its wholly owned Mexican facilities (Reyer, 2012). Johnson Controls considers U.S. batteries processed in Mexico to be an integral part of its closed-loop system, and it appears to include this material when it reports a 97 percent recycling rate for the United States (Johnson Controls, 2013).

None of these estimates takes into account lead in spent batteries placed in temporary storage by consumers or retailers, lead lost in slag, or lead contained in spent batteries deposited in municipal waste. Should this material be considered, it is likely that the U.S. lead recycling rate would be lower than the reported estimates, perhaps as low as 66 percent (Genaidy and others, 2008).

The EPA reports estimates for the quantity of lead-acid batteries generated, recovered, and discarded in the municipal waste stream, based on data developed by Franklin Associates (U.S. Environmental Protection Agency, 2011b). These estimates suggest that the percentage of lead-acid batteries recovered from the municipal waste stream from 2000 to 2010 averaged 95.5 percent and that about $112,000 \mathrm{t}$ was discarded annually into the municipal waste stream during the last decade. The amount discarded in 2010, 120,000 t, was about half of the quantity discarded annually during 1970-90. Values reflect total battery weight, not the weight of contained lead. 


\section{Trade Patterns}

Although the United States has been a net importer of refined lead metal and a net exporter of lead scrap for the entire study period from 1998 through 2012, no single trend is apparent when viewed in terms of the trade of lead contained in batteries. Slightly more lead was contained in exported batteries than imported batteries in 1998. From 1999 through 2006, more lead was estimated to be contained in imported batteries than in exported batteries. Since 2006, however, more lead was estimated to be contained in battery exports than in battery imports, primarily owing to increased exports of used batteries for recycling.

Figure 7 shows estimates for the lead content of battery imports and exports by category for 1998 through 2012 . The figure illustrates significant growth of both imports and exports during the period. As shown in figure $7 \mathrm{~A}$, the lead content of vehicle batteries imported into the United States grew rapidly as U.S. demand for new vehicles increased and domestic vehicle manufacturing plants came into production. Between 1998 and 2004, the annual growth rate of lead battery imports expressed in terms of lead content averaged 12 percent. With the economic downturn that began in 2007 , demand for vehicles in the United States decreased, resulting in a reduction in the number of vehicle batteries imported to supplement domestic auto battery production. The annual growth rate of lead battery imports expressed in terms of lead content for the years 2004 through 2012 was about 1 percent. Changes in the economy during 2007-10 did not appear to affect used battery or stationary battery markets significantly because both imports and exports of these batteries appeared to reflect continued growth for the entire study period, as measured by the total lead content of these battery classes.

The data shown in figure $7 B$ suggest that used battery exports increased significantly after 2005. From 1998 to 2004, the annual growth rate of lead battery exports expressed in terms of lead content averaged 2 percent. The annual growth rate of lead battery exports expressed in terms of lead content for the years 2004 through 2012 was 13 percent. In 2004, Johnson Controls acquired the Ciénega secondary smelter in Mexico and began directing both U.S.- and Mexican-generated spent lead-acid batteries (SLABs) to that facility for recycling. In 2011, Johnson Controls opened the García secondary smelter in Mexico. As of 2011, Johnson Controls' operations in Mexico accounted for 74 percent of all SLAB exports from the United States to Mexico (Commission for Environmental Cooperation, 2012, p. 23).

Since the North American Free Trade Agreement took effect in 1994, trade among the United States, Canada, and Mexico has increased significantly. Data reported by the Commission for Environmental Cooperation (CEC) suggest that exported SLABs from the United States to Mexico increased by at least 450 percent and that SLAB exports to Canada increased at least 200 percent from 2004 through 2011. Site modifications implemented to meet the stricter environmental performance standards in Canada and the United States have increased capital costs and contributed to increased vertical integration and internationalization of the secondary lead industry, in order to maximize efficiencies of scale in the secondary smelting and battery recycling sectors (Commission for Environmental Cooperation, 2012, p. 15).

Trade data for lead scrap and used lead-acid batteries as reported by the USGS, EPA, ISRI, and USITC for 1998 through 2012 show significant shifts in trade patterns for these secondary lead products. Figure 8 shows estimates of the quantity of lead contained in imported lead scrap and used lead-acid batteries from selected countries or regions. Import data for lead scrap can be broken out into three timeframes: 1998 through 2001, 2002 through 2009, and 2010 through 2012. Approximately $12,000 \mathrm{t}$ of lead scrap was imported annually into the United States from 1998 through 2001, and much of the lead scrap was imported from Canada, Mexico, and South America. About 5,000 t of lead scrap was imported annually from 2002 through 2009, primarily from Canada and Central America (excluding Mexico). Decreased lead scrap shipments from South America and Canada accounted for the reduced scrap imports during this period. Since 2010, the quantity of lead scrap imports to the United States averaged 14,000 t per year, primarily from Central America and South America.

The source pattern for lead imports depends to a large degree on the category of material being imported. In 1998, imports of used lead-acid batteries came primarily from Canada (more than 99 percent of total used battery imports). Percentages were calculated on the basis of lead content from data reported by the U.S. International Trade Commission as revised by the U.S. Census Bureau. In 2012, the principal sources of used lead-acid batteries were Canada ( 95 percent) and Central America (excluding Mexico) (4 percent). Imports of lead scrap from batteries and other sources came primarily from Canada (59 percent), South America (28 percent), and Mexico (8 percent) in 1998 and from Central America, excluding Mexico (77 percent), Mexico (13 percent), and Canada (5 percent) in 2012.

U.S. import data for used lead-acid batteries (SLABs) are also shown in figure 8. In 1998, about 17,000 t of lead contained in used batteries was imported into the United States, almost all coming from Canada. In 2012, about 26,000 t of lead contained in used batteries was imported, of which 95 percent came from Canada. Although some of these batteries may be reexported, it is believed that the secondary lead industry in the United States recovers most of the lead from imported batteries for subsequent reuse in new batteries.

Figure 9 shows the growth in the quantity of lead contained in scrap and used lead-acid batteries exported from the United States from 1998 through 2012. Trade data suggest that the amount of lead scrap exported from the United States has decreased from about 99,000 t per year in 1998 to about $26,000 \mathrm{t}$ in 2012, in response to the partial shift in lead-acid battery recycling from the United States to Mexico. Principal destinations of lead scrap generated in the United States from 1998 through 2012 (fig. 9) were Canada, Southeast Asia, and 
A. Lead content of battery imports

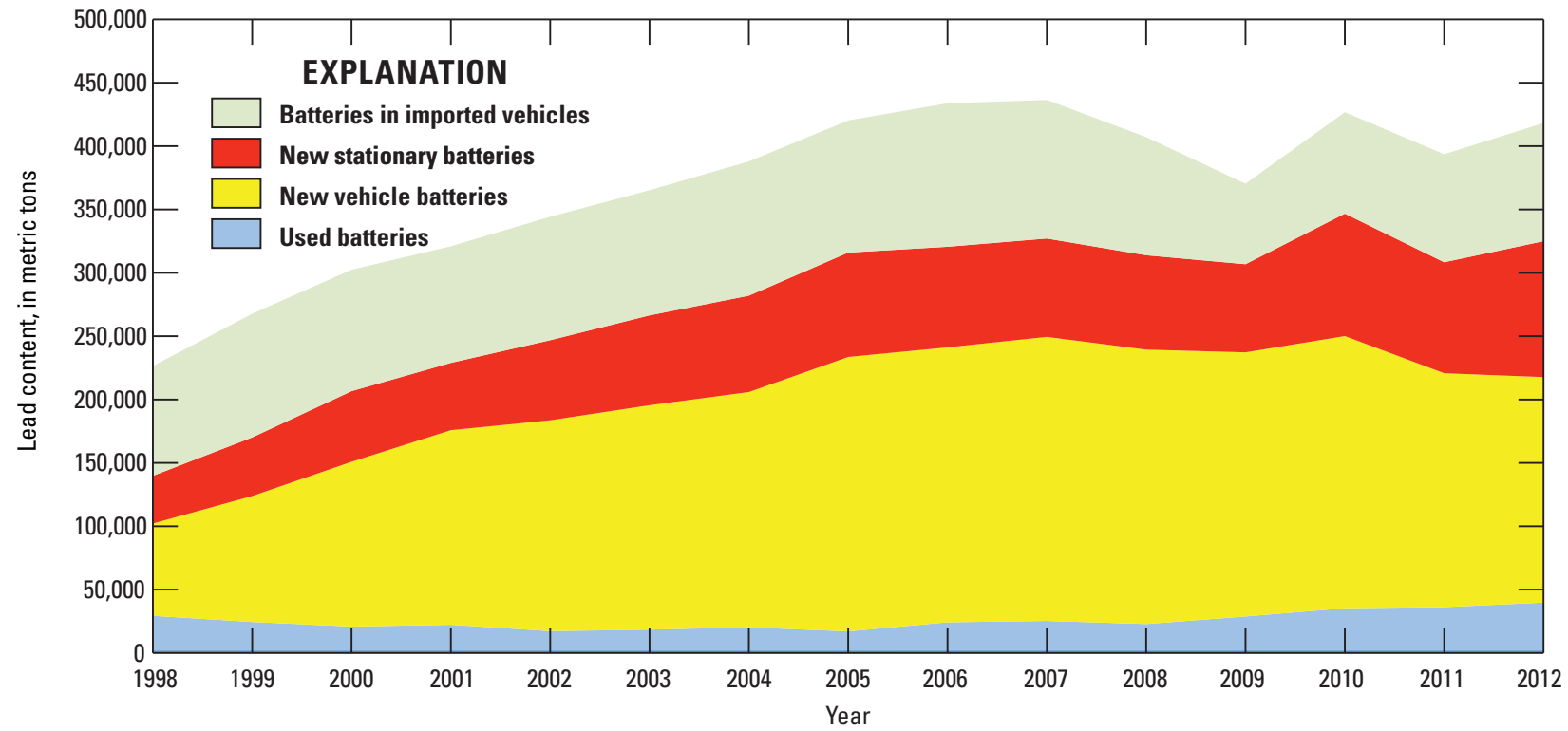

\section{B. Lead content of battery exports}

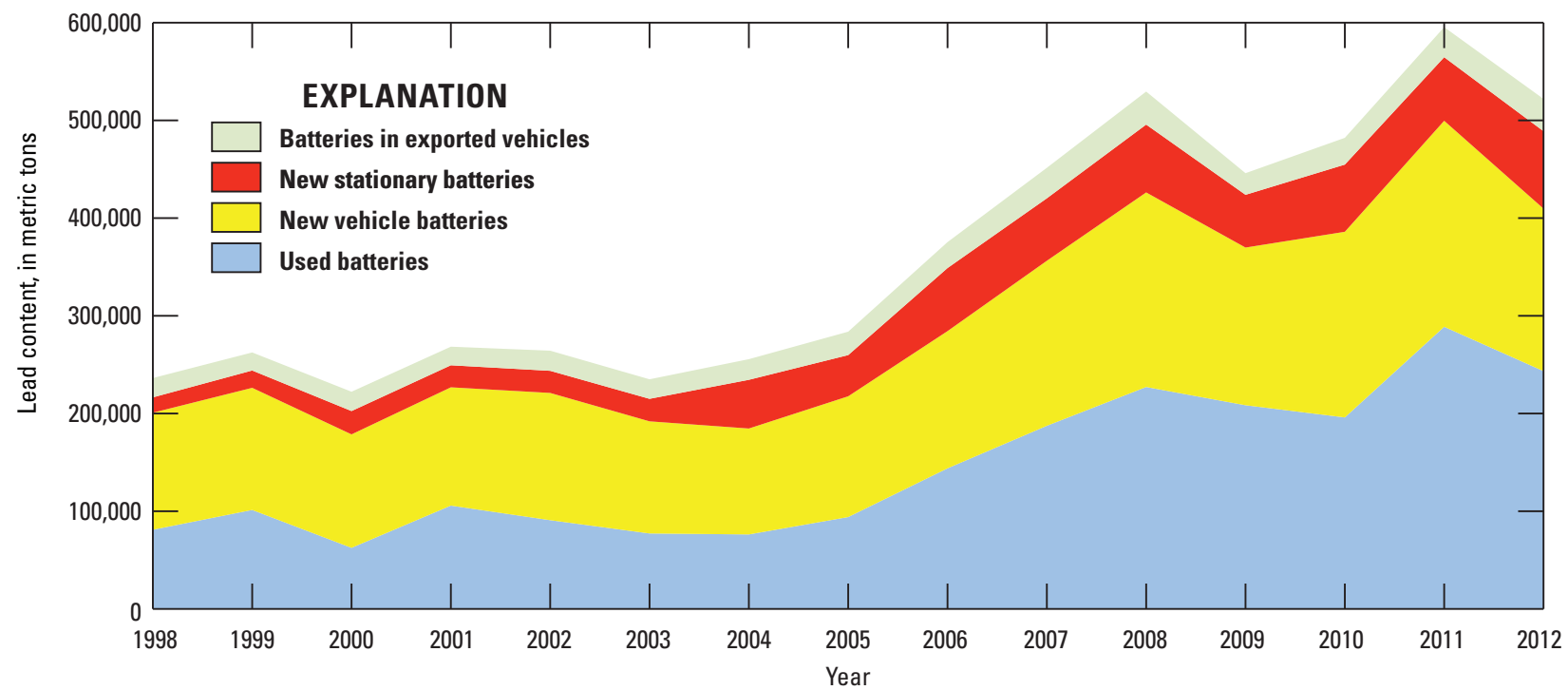

Figure 7. Lead content of $A$, battery imports, and $B$, battery exports, by category, 1998 through 2012. Data are from International Trade Commission (2013), with revisions based on corrections reported in U.S. Census Bureau (2013). 


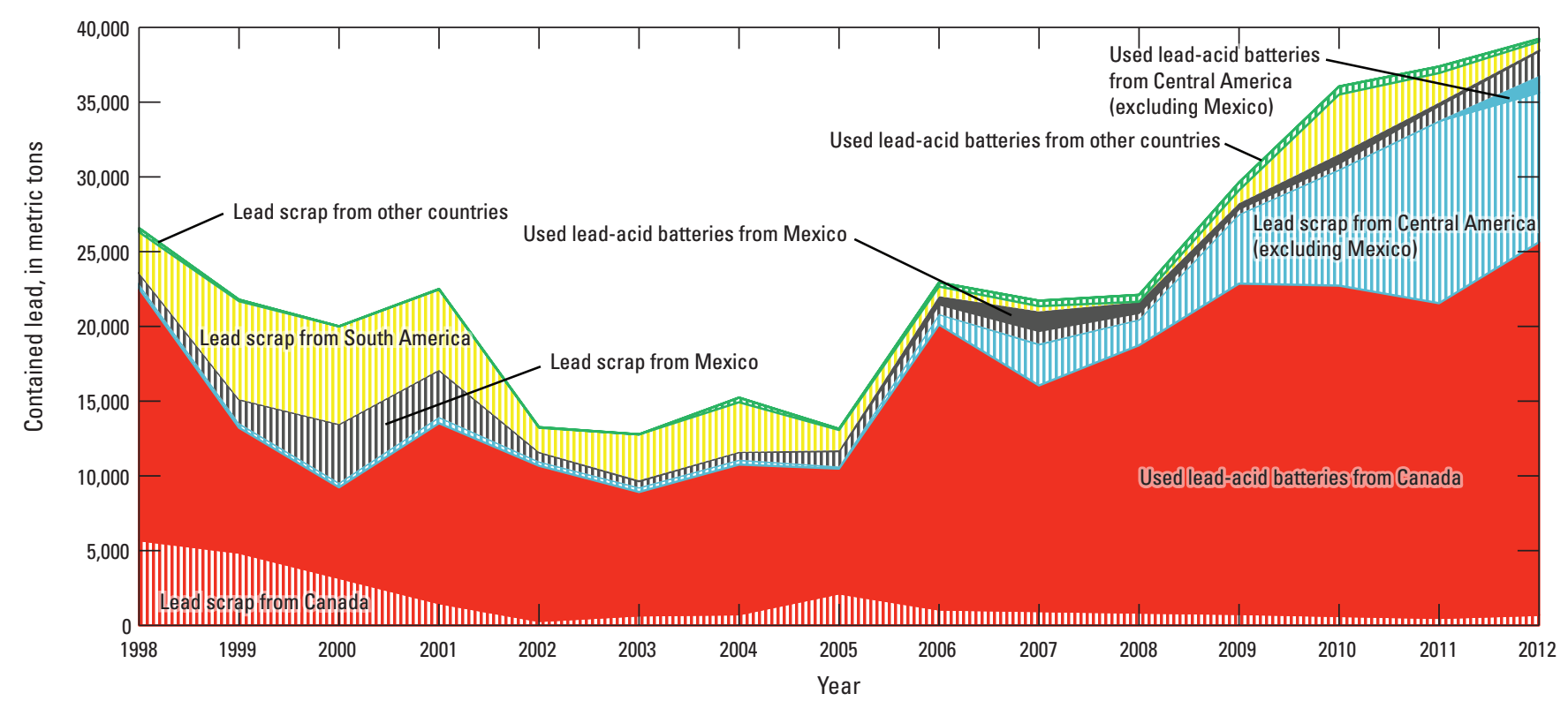

Figure 8. Imports of lead contained in lead scrap and used lead-acid batteries to the United States from selected countries or regions, 1998 through 2012. Lead scrap includes battery scrap and nonbattery scrap. Scrapped lead-acid batteries reported separately. Data are from U.S. Geological Survey (2012) and U.S. International Trade Commission (2013), with revisions based on U.S. Census Bureau data, various years.

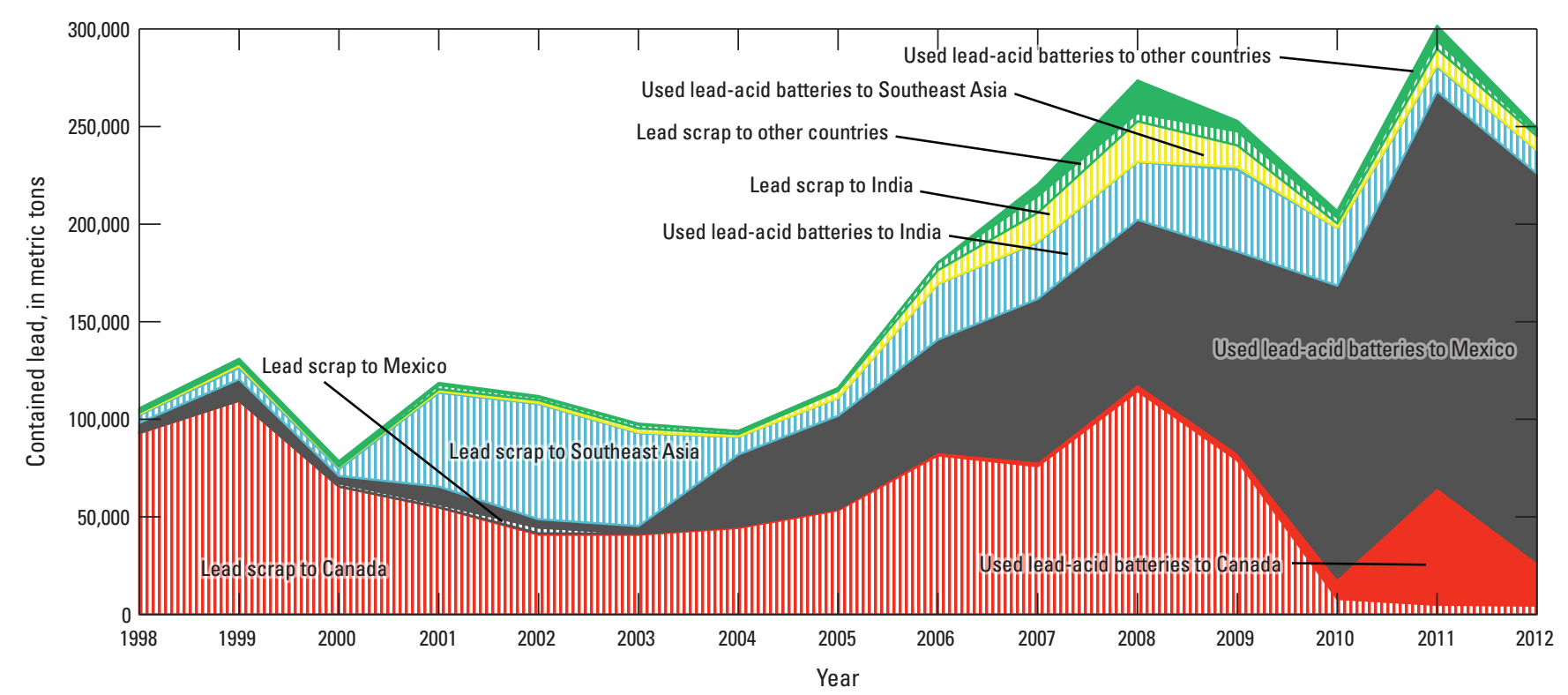

Figure 9. Exports of lead contained in lead scrap and used lead-acid batteries to the United States from selected countries or regions, 1998 through 2012. Lead scrap includes battery scrap and nonbattery scrap. Scrapped lead-acid batteries reported separately. Data are from U.S. Geological Survey (2012) and U.S. International Trade Commission (2013), with revisions based on U.S. Census Bureau data, various years. 
India. Two secondary lead smelters in Ontario and Quebec processed about 93 percent of the imported lead scrap to Canada. It is possible, however, that some scrap lead-acid batteries exported to Canada prior to 2010 were improperly classified as lead scrap until 2010, when increased scrutiny by the EPA and U.S. Customs and Border protection identified and made attempts to rectify this problem (Commission for Environmental Cooperation, 2012; Guberman, 2012). If so, then the reported decrease in lead scrap exports to Canada from 2008 to 2010 may be partially offset by the reported rise in the quantity of used lead-acid batteries exported to Canada after 2009.

Figures 8 and 9 show that in 1998 lead scrap and scrap battery exports primarily went to Canada. The United States exported about four times more lead scrap and batteries than it imported in 1998. By 2012, the United States imported lead scrap primarily from Central America (excluding Mexico) and scrap batteries primarily from Canada. Lead scrap exports were sent primarily to Southeast Asia and scrap batteries to Canada and Mexico. U.S. exports of lead from scrap and scrap batteries accounted for more than six times the amount imported into the United States. Although Canada remains a principal source of lead scrap, Mexico has become the principal destination for scrap batteries.

Scrapped lead-acid batteries not recycled in the United States were exported primarily to Canada, Mexico, and Asia for recycling. In 1998, the three countries receiving the most scrapped batteries from the United States were Canada ( 82 percent, expressed in terms of number of batteries), Mexico ( 7 percent), and China (2 percent). In 2012, the three largest recipients of scrap lead-acid batteries from the United States were Mexico (83 percent), Canada (11 percent), and the Republic of Korea (2 percent).

Exports of used lead-acid batteries (SLABs) have increased from about 6,000 t of contained lead in 1998 to over 270,000 t in 2011. Battery exports to Mexico averaged about 6,000 t per year of contained lead during the 1998-2003 period, about $69,000 \mathrm{t}$ per year for the 2004-09 period, and $183,000 \mathrm{t}$ per year for the 2010-12 period. Lead contained in battery exports to Canada increased from about 2,000 $t$ in 2006 to over $60,000 \mathrm{t}$ in 2011 , if the revised USITC data are correct.

Data compiled by the CEC for SLAB exports to Mexico and Canada substantiate the significant growth trend in used battery exports from the United States since 1998, even if data from various sources are inconsistent. SLAB data are included in the used battery data shown in figures 7-11. The CEC report pointed out some reporting errors with the USITC data and inconsistencies in the reported values of the USITC, EPA, and Environment Canada data, likely due to possible reporting errors or different systems of battery classification. The EPA and USITC uses the U.S. Census Bureau Harmonized Trade Code (HTS) system, whereas Environment Canada uses a system developed by the United Nations, which can include small sealed cell batteries used by the electronics industry not included in the HTS classifications used in this study. The data for 2011 SLAB exports to Canada from the United States reflect a variation of 1.6 percent between the EPA and USITC data and 8.5 percent between the Environment Canada and USITC data (Commission for Environmental Cooperation, 2012, p. 28). The data for 2011 SLAB exports to Mexico from the United States reflect a variation of 13.8 percent between the EPA and unrevised USITC data; 13.3 percent between data reported by Mexico's Procuraduría Federal de Protección al Ambiente (Profepa) and the data reported by the USITC before being revised (Commission for Environmental Cooperation, 2012, p. 24). The trade data used in this report reflect the most recent estimates of USITC data based on revisions released by the U.S. Census Bureau (2013). Although differences between USITC-reported values and EPA estimates have not been reconciled, the general trends illustrated in this report should still be valid.

Figures 10 and 11 show the total amount of lead estimated to be contained in lead scrap and used lead-acid batteries imported and exported to Canada and Mexico for the period 2000 through 2012, expressed in terms of a percent ratio of lead imported or exported to Canada or Mexico to the total lead for all U.S. exports of batteries and scrap based on the revised data collected by the U.S. Census Bureau and reported by the USITC. As shown in figure 10, the contribution of the total lead contained in batteries and battery scrap imported from Mexico to the United States ranged from 36 to 45 percent for the years 2000 through 2012; the contribution of the total lead contained in batteries and battery scrap imported from Canada ranged from 9 to 18 percent.

In 1998, the three largest sources of imported new leadacid batteries were Mexico (62 percent, expressed in terms of number of batteries), Taiwan (10 percent), and Canada (5 percent). In 2012, the three largest importers were Mexico (52 percent), China (21 percent), and the Republic of Korea (9 percent). The growing Chinese battery industry and Korean automotive industry have led to increased battery production from these sectors at the expense of the Canadian and Taiwanese battery sectors. Approximately 73,000 t of lead was contained in new vehicle battery imports in 1998, and about $178,000 \mathrm{t}$ of lead was contained in new vehicle battery imports in 2012 .

The three largest export destinations for new lead-acid batteries in 1998 were Canada (27 percent), Mexico (16 percent), and Japan (8 percent). In 2012, the three largest export destinations were Canada (31 percent), Mexico (10 percent), and the Dominican Republic (5 percent). Some of these batteries may subsequently be placed in vehicles that are intended for the U.S. market. Approximately 120,000 t of lead was contained in new vehicle batteries exported from the United States in 1998, and about $166,000 \mathrm{t}$ of lead was contained in new vehicle batteries exported in 2012.

New imported vehicles containing lead-acid batteries originated primarily from Asia, Canada, and Europe, but a significant number came from Mexico. In 1998, the three largest sources of new vehicle imports with batteries came from Japan (47 percent, expressed in terms of number of vehicles), 


\section{A. Lead from batteries and lead scrap imported from Mexico}

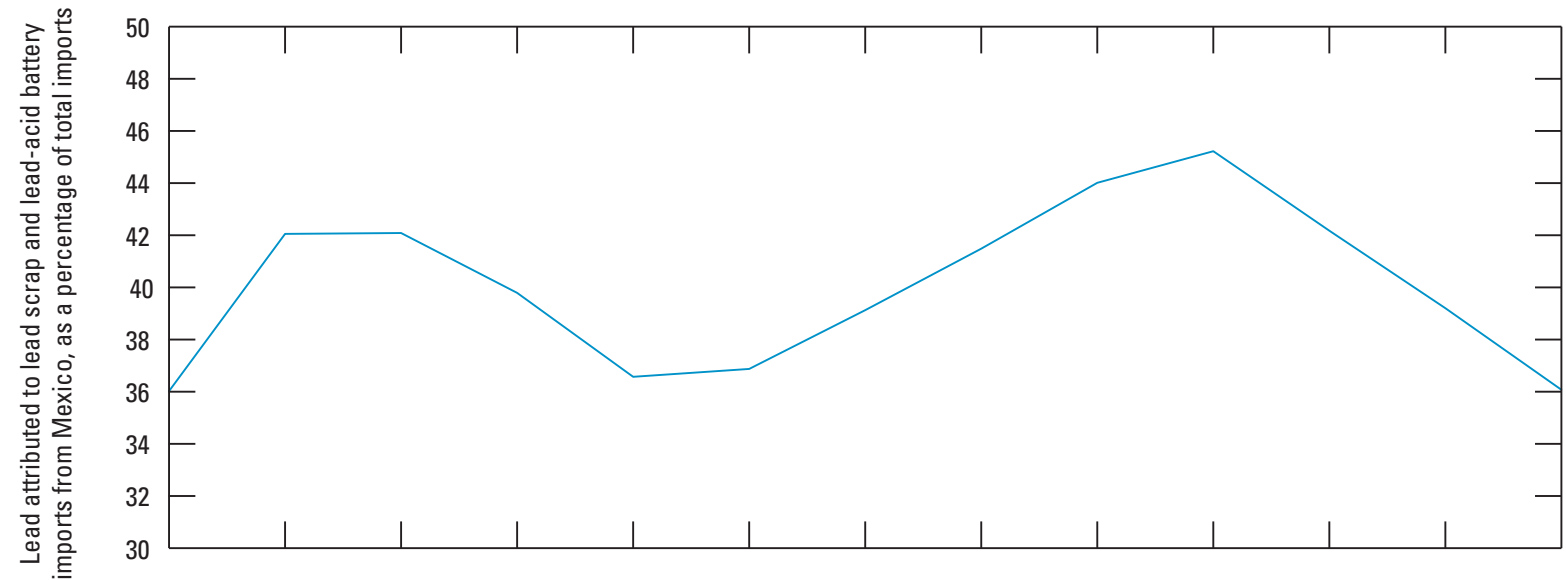

\section{B. Lead from batteries and lead scrap imported from Canada}

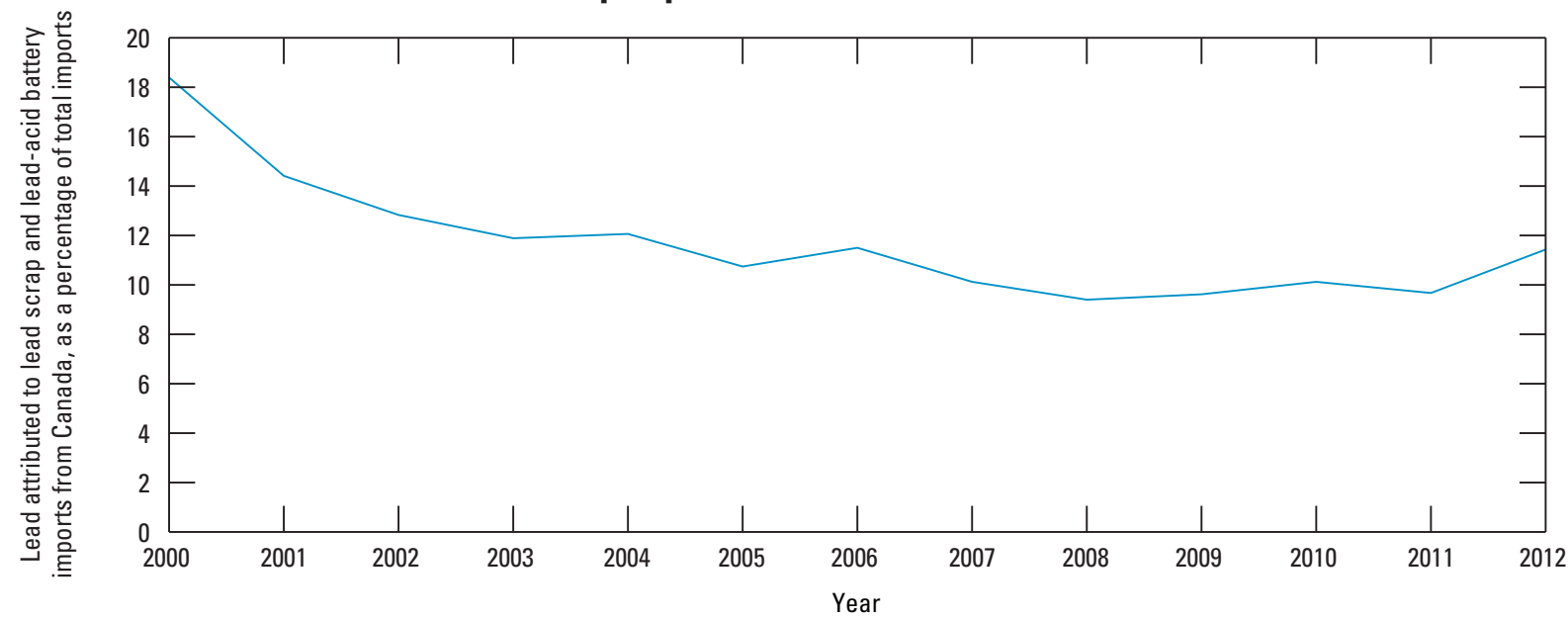

Figure 10. Contribution of $A$, Mexico, and $B$, Canada, in terms of percentage of lead contained in imported lead scrap and lead-acid batteries, 2000 through 2012. Data are from U.S. International Trade Commission (2013), with revisions based on corrections reported by the U.S. Census Bureau (2013).

Canada (27 percent), and Germany (10 percent). In 2012, the three largest sources were Japan (29 percent), Canada (22 percent), and Mexico (17 percent). In 1998, approximately $87,000 \mathrm{t}$ of lead was contained batteries in new imported vehicles; about 93,000 t of lead was contained in batteries in vehicles imported in 2012.

In 1998, the three largest export destinations of new vehicles containing lead-acid batteries were Canada (50 percent), Mexico (9 percent), and Japan (4 percent). In 2012, the three largest destinations were Canada (31 percent), Mexico ( 8 percent), and Saudi Arabia (6 percent). These vehicles contain lead-acid batteries that were manufactured in the United States or imported into the United States then assembled in vehicles. Exported vehicles accounted for about 20,000 t of exported lead in 1998 and about 33,000 t of lead in 2012.
As shown in figure 11, lead battery exports to Mexico increased significantly starting in 2003. In 2003, Mexico accounted for about $16,000 \mathrm{t}$ ( 6 percent) of the total lead contained in exported batteries and lead scrap from the United States; by 2012, Mexico accounted for about 250,000 t (47 percent) of the total lead contained in exported batteries and lead scrap. In 2000, about 47 percent of this lead exported to Mexico was contained in new vehicle batteries, 28 percent of the lead was contained in used vehicle batteries, 13 percent of the lead was contained in stationary batteries, and 12 percent of the lead was found in exported vehicles containing batteries. In 2012, the distribution of lead had shifted such that about 86 percent of the exported lead was contained in used vehicle batteries, 9 percent was contained in new vehicle batteries, 4 percent was contained in stationary batteries, and the remaining 1 percent of the lead was found in exported 


\section{A. Lead from batteries and lead scrap exported to Mexico}

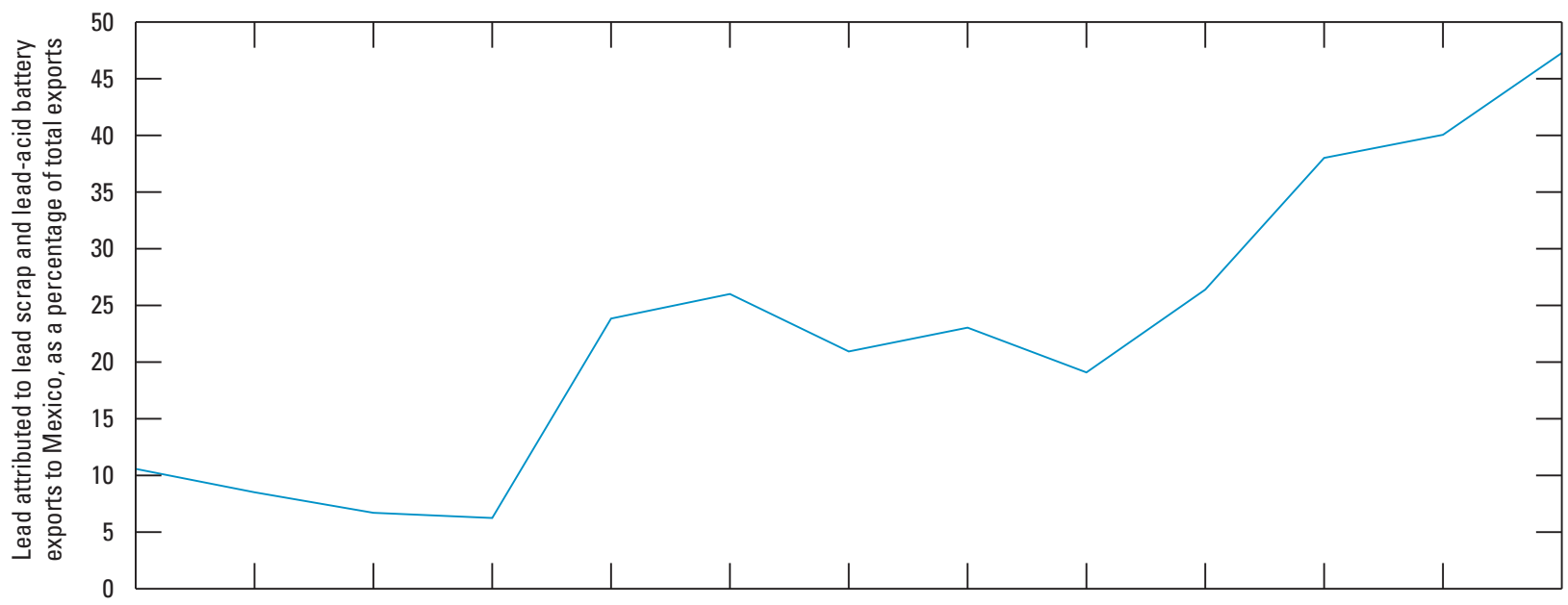

B. Lead from batteries and lead scrap exported to Canada

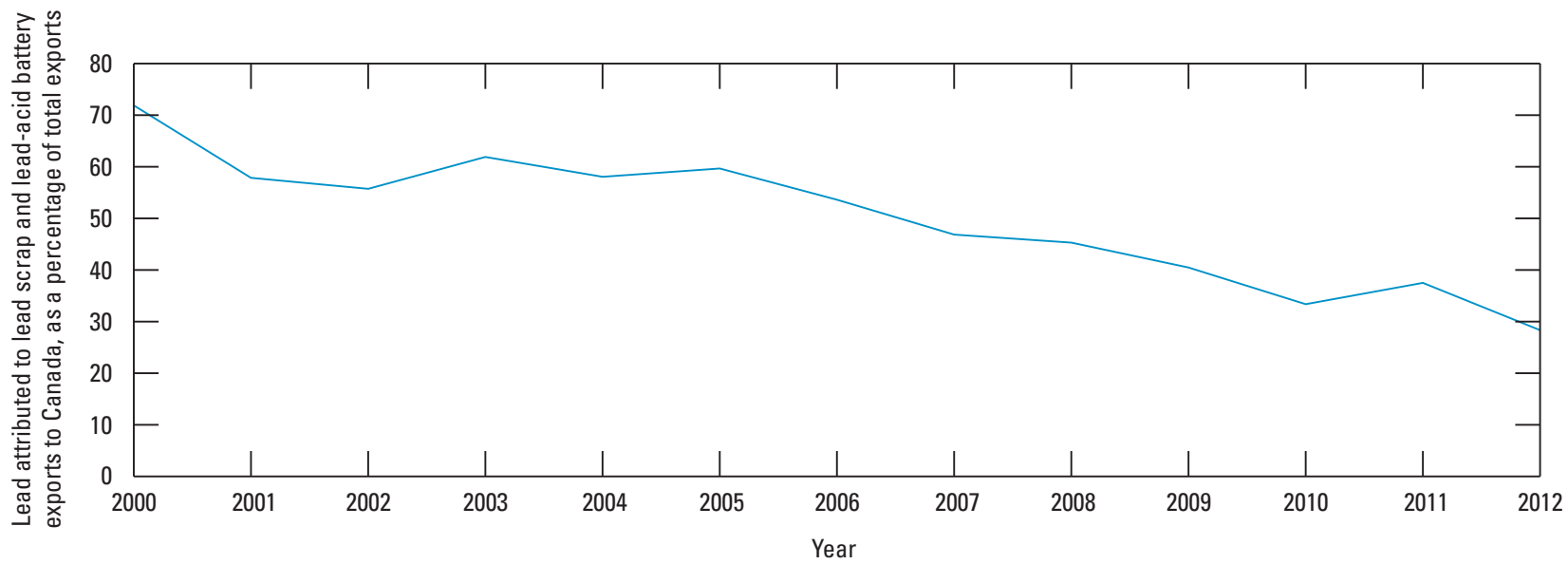

Figure 11. Contribution of $A$, Mexico, and $B$, Canada, in terms of percentage of lead contained in exported new and used lead-acid batteries and lead scrap, 2000 through 2012. Data are from U.S. International Trade Commission (2013), with revisions based on corrections reported by the U.S. Census Bureau (2013).

vehicles containing batteries. Since the opening of the Johnson Controls lead recycling plants in Mexico, a greater percentage of used lead-acid batteries from the United States was being recycled in Mexico. No data were available on the amount of the lead recycled in Mexico that came back to the United States either as batteries or as battery scrap intended for reuse by the U.S. battery industry.

The amount of lead contained in batteries and battery scrap being exported to Canada showed a downward trend for the same period. In 2000, Canada accounted for about 72 percent of the total lead contained in exported batteries and battery scrap exported from the United States; by 2012, Canada accounted for about 28 percent, even though the total lead content of this material decreased only about 7 percent since 1998. The change in the amount of lead attributed to exports to Canada can be tied to the large increase in secondary lead exports going to Mexico. In 2000, about 54 percent of the lead in batteries and battery scrap exported to Canada was contained in new vehicle batteries, 37 percent of the lead was contained in used vehicle batteries, 7 percent of the lead was found in exported vehicles containing batteries, and 2 percent of the lead was contained in stationary batteries. In 2012, the distribution of lead exported to Canada was about 67 percent contained in new vehicle batteries, 19 percent contained in used vehicle batteries, 8 percent in exported vehicles containing batteries, and the remaining 6 percent contained in stationary batteries. Two secondary lead smelters, one in Ontario and one in Quebec, received about 93 percent of the battery scrap from the United States in 2011 (Commission for Environmental Cooperation, 2012, p. 27) . 


\section{Outlook for Lead Recycling}

With the closure of the last primary lead smelter in the United States in 2013, the secondary lead industry became the sole source of domestic lead production. More stringent environmental regulations have increased capital costs of secondary smelters and made it more difficult for smaller, less profitable smelters to remain competitive. It is likely that additional industry consolidation and vertical integration will take place. Remaining smelters will likely demonstrate higher environmental performance, striving for improved capacity utilization and efficiencies of scale.

Because lead is considered a potentially toxic material, use of lead in certain applications has decreased. Newer battery technologies are under development that may reduce or eliminate the use of lead in certain applications, so lead consumption in these applications may decrease.

Vertical integration has become more common in the North American secondary lead industry. Four major North American battery manufacturers, East Penn Manufacturing Company, Exide Technologies Manufacturing Company, Grupo Gonher de Mexico, and Johnson Controls have vertically-integrated operations in the United States and (or) Mexico in their supply chains. In Mexico, costs are lower and environmental regulation is presently less stringent. Ambient air standards for lead in the United States were revised and made more stringent in 2008, as were lead emissions standards at battery recycling facilities in 2012. Some small foreign secondary facilities that are undercapitalized may not be able to make the improvements in environmental management that are necessary to reduce lead emissions to the level achievable in the United States and still remain competitive with larger, better-capitalized operations (Commission for Environmental Cooperation, 2012, p. 5).

The United States, unlike Canada and Mexico, does not require a hazardous waste manifest to accompany each shipment of spent lead-acid batteries or battery waste. Although the United States was one of the first signatories of the Basel Convention on the Control of Transboundary Movements of Hazardous Wastes and Their Disposal, the U.S. Congress has not yet enacted the requisite implementing legislation bringing U.S. law into conformity with the terms of the Convention, so shipping manifests are not mandated (Bradford, 2011). As more lead-bearing battery materials are exported to countries such as Mexico that may have less stringent environmental standards than in the United States, greater pressure is placed on the United States to adopt manifesting requirements and for countries receiving battery waste from the United States to adopt similar environmental standards. However, the cost gap between U.S. and foreign recycling of lead batteries is likely to grow more pronounced with the implementation of new U.S. standards (due in January 2014).

The percentage of U.S. lead consumption attributed to the recycling of lead-acid batteries is expected to grow in response to curtailment of domestic primary lead production and increases in battery scrap processing as new domestic secondary production capacity comes into production. However, competition for the recycling of spent batteries is expected to increase as lead recycling costs increase and noncompetitive operations close or reduce capacity, as new capacity at facilities in Florida and South Carolina come into production, and if exports of used batteries to Mexico continue at high levels. Some companies without well-established collection systems or long-term marketing contracts may find it difficult to compete. U.S. secondary lead producers are increasingly competing with Canadian and Mexican facilities for market share. Johnson Controls estimates the North American lead recycling industry will spend nearly $\$ 600$ million to meet the new environmental standards (Norton, 2012). Because of these constraints, it is unlikely that the U.S. secondary lead industry will grow in the short term beyond the capacity increases already anticipated.

Data suggest that a significant amount of lead is yet unaccounted for in its life cycle (Genaidy and others, 2008). There are several sources of lead scrap where recycling rates could be improved, and there are other sources that should be considered as future recycling opportunities. Although actual data on the amount of material recycled from these sources are limited, studies suggest that a considerable amount of lead is contained in batteries stored by consumers or auto salvage yards, slag generated from lead recycling facilities, and material disposed in municipal waste. Figure 2 suggests that as much as 366,000 t of lead scrap was unrecovered, stored, lost, or landfilled in 2010. It is likely, however, that some of this lead is contained in products in which the lead is dispersed or scattered, making recycling difficult or costly, or contained in exported products where the quantity of contained lead has not been reported.

Data compiled by the National Automobile Dealers Association (2012) show that the average age for passenger cars and light trucks still in use has increased from about 9 years in 2001 to almost 11 years in 2011, suggesting that there may be an increasing number of vehicles available for scrap in the future. Unless the vehicle battery is removed and recycled prior to vehicle disposal, the number of lead-acid batteries contained in used vehicles or vehicle scrap should increase when these older vehicles are sold, exported, or scrapped. If future market conditions stimulate the replacement of these vehicles with new vehicles, then the proportion of lead attributed to new vehicle batteries will likely increase. 


\section{References Cited}

Battery Council International, 1998, National recycling rate study: Chicago, Ill., prepared by Smith, Bucklin, and Associates, Inc., 19 p.

Battery Council International, 2003, National recycling rate study: Chicago, Ill., prepared by Smith, Bucklin, and Associates, Inc, 11 p., accessed April 15, 2013, at http://www. batterycouncil.org/statistics/BCIRecyclingRateReport.pdf.

Battery Council International, 2005, National recycling rate study: Chicago, Ill., prepared by Smith, Bucklin, and Associates, Inc., 11 p., accessed April 15, 2013, at http:// www.solidwastedistrict.com/statistics/recycling_rate_study_ july_2003.pdf.

Battery Council International, 2012, National recycling rate study: Chicago, Ill., prepared by Smith, Bucklin, and Associates, Inc., 9 p., accessed April 15, 2013, at http:// archive.batterycouncil.org/Portals/0/BCI\%20Recycling $\% 20$ Rate\%20Study\%202007\%20-\%202011\%20Final\%20 Report.pdf.

Battery Council International, 2013, State recycling laws, accessed April 24, 2013, at http://batterycouncil. org/?page=State_Recycling_Laws.

Bleiwas, D.I., 2006, Stocks and flows of lead-based wheel weights in the United States: U.S. Geological Survey OpenFile Report 2006-1111, 6 p., accessed May 15, 2013, at http://pubs.usgs.gov/of/2006/1111/.

Bradford, Mark, 2011, The United States, China, and the Basel Convention on the transboundary movements of hazardous wastes and their disposal: Fordham Environmental Law Review, v. 8, no. 2, p. 305-349, accessed September 13, 2013, at http://ir.lawnet.fordham.edu/cgi/viewcontent. cgi? article $=1445$ \& content $=$ elr.

Commission for Environmental Cooperation, 2012, Hazardous trade?-An examination of US-generated spent lead-acid battery exports and secondary lead recycling in Mexico, the United States, and Canada: Secretariat of the Commission for Environmental Cooperation, November 30, 70 p., accessed April 8, 2013, at http://www.cec.org/ Storage/142/16758_SLAB-publicdraft-30Nov_en.pdf.

Environment News Service, 2010, Lead giant to shut Missouri smelter early, pay $\$ 72$ million for violations, accessed May 13, 2013, at http://www.ens-newswire.com/ens/ oct2010/2010-10-12-092.html.
Genaidy, A.M., Sequeira, R., Tolaymat, T., Kohler, J., and Rinder, M., 2008, An exploratory study of lead recovery in lead-acid battery lifecycle in US market-An evidencebased approach: Science of the Total Environment, v. 407, p. 7-22, accessed April 24, 2013, at http://www.elsevier. com/locate/scitotenv.

Guberman, D.E., 2012, Lead, in Metals and minerals: U.S. Geological Survey Minerals Yearbook 2010, v. I, p. 42.142.18, accessed May 15, 2013, at http://minerals.er.usgs. gov/minerals/pubs/commodity/lead/myb1-2010-lead.pdf.

Guberman, D.E., 2013, Lead, in Metals and minerals: U.S. Geological Survey Minerals Yearbook 2011, v. I, p. 42.142.18, accessed May 15, 2013, at http://minerals.er.usgs. gov/minerals/pubs/commodity/lead/myb1-2011-lead.pdf.

Institute of Scrap Recycling Industries, Inc., 2012, The ISRI scrap yearbook 2012: Washington, D.C., 47 p.

Johnson Controls, 2013, Leading the way in battery recycling, accessed May 8, 2013, at http://www.johnsoncontrols. com/content/dam/WWW/jci/ps/press_kit/22083_JCI_ FSRecycling_RL_1-2.pdf.

National Automobile Dealers Association, 2012, NADA Data 2012 - State-of-the industry report: McLean, Va., 21 p.

Norton, Karen, 2012, Rising lead recycling costs may prompt cutbacks: Thomson Reuters, March 26, accessed December 12, 2012, at http://www.reuters.com/assets/ print? aid $=$ USBRE82P0HC20120326.

Occupational Knowledge International, 2011, Exporting hazards - U.S. shipments of used lead batteries to Mexico take advantage of lax environmental and worker health regulations: Occupational Knowledge International and Fronteras Comunes [variously paged], accessed May 15, 2013, at http://www.okinternational.org/docs/Exporting\%20 Hazards_Study_100611v5.pdf.

Papp, J.F., 2013, Recycling-Metals, in Metals and minerals: U.S. Geological Survey Minerals Yearbook 2011, v. 1, p. 61.1-61.5, accessed June 15, 2013, at http://minerals. er.usgs.gov/minerals/pubs/commodity/recycle/myb1-2011recyc.pdf.

Recycling Today, 2013, Exide idles California lead smelter, accessed May 15, 2013, at http://www.recyclingtoday.com/ exide-vernon-lead-smelter-compliance.aspx.

Reyer, R.M., 2012, Battery Council International submission of comments on CEC Secretariat report on the transboundary movement and recycling of spent lead-acid batteries: Battery Council International, June 12, accessed May 15, 2013, at http://www.cec.org/Storage/138/16304_BCI_ Comments_to_CEC_06_12_2012.pdf. 
Schmidt, C.W., 2010, Lead in air-Adjusting to a new standard: Environmental Health Perspectives, v. 118, no 2, p. A76-A79, accessed April 25, 2013, at http://www.ncbi.nlm. nih.gov/pmc/articles/PMC2831943/.

Smith, G.R., 1999a, Lead, in Metals and minerals: U.S. Geological Survey Minerals Yearbook 1998, v. I, p. 44.1-44.24, accessed June 12, 2013, at http://minerals.er.usgs.gov/ minerals/pubs/commodity/lead/380498.pdf.

Smith, G.R., 1999b, Lead, in Mineral commodity summaries 1999: U.S. Geological Survey, p. 98-99.

Smith, G.R., 2004, Lead recycling in the United States in 1998, chap. F of Sibley, S.F., ed., Flow studies for recycling metal commodities in the United States: U.S. Geological Survey Circular 1196, accessed April 24, 2013, at http:// pubs.usgs.gov/circ/2004/1196am/c1196a-m_v2.pdf.

U.S. Census Bureau, 2013, Statistical notices and corrections, accessed April 26, 2013, at http://www.census.gov/foreigntrade/statistics/corrections/indux.html.

U.S. Environmental Protection Agency, 1997, National emission standards for hazardous air pollutants from secondary lead smelting - Direct final rule-Amendments to rule: Federal Register, v. 62, no. 114, June 13, p. 32209.

U.S. Environmental Protection Agency, 2000, National air pollutant emission trends, 1900-1998: Office of Air Quality Planning and Standards, p. 3-15, accessed April 14, 2013, at http://www.epa.gov/ttnchie1/trends/trends98/trends98.pdf.

U.S. Environmental Protection Agency, 2011a, Electronics waste management in the United States through 2009: Office of Resource Conservation and Recovery, accessed April 14, 2013, at http://www.epa.gov/osw/conservel materials/ecycling/docs/fullbaselinereport2011.pdf.

U.S. Environmental Protection Agency, 2011b, Municipal solid waste generation, recycling, and disposal in the United States-Table and figures for 2010: Office of Resource Conservation and Recovery, accessed April 14, 2013, at http://www.epa.gov/osw/nonhaz/municipal/pubs/2010_ MSW_Tables_and_Figures_508.pdf.
U.S. Environmental Protection Agency, 2012a, 40 CFR Part 63-National emissions standards for hazardous air pollutants from secondary lead smelting, final rules: Federal Register, v. 77, no. 3, January 5, p. 556-591.

U.S. Environmental Protection Agency, 2012b, Statistics on the management of used and end-of-life electronics: Wastes, resource conservation, common wastes, and materials Web page, accessed May 16, 2013, at http://www.epa.gov/osw/ conserve/materials/ecycling/manage.htm.

U.S. Environmental Protection Agency, 2013, Batteries: Wastes, resource conservation, common wastes and materials Web page, accessed April 24, 2013, at http://www.epa. gov/waste/conserve/materials/battery.htm.

U.S. Geological Survey, 1999-2013, Minerals Yearbook, v. 1, 1998-2011.

U.S. Geological Survey, 2012, Lead statistics, in Kelly, T.D., and Matos, G.R., comps., Historical statistics for mineral and material commodities in the United states: U.S. Geological Survey Data Series 140, accessed April 24, 2012, at http://minerals.usgs.gov/ds/2005/140/ds/140-lead.pdf.

U.S. Geological Survey, 2013a, Metal prices in the United States through 2010: U.S. Geological Survey Scientific Investigations Report 2012-5188, 204 p., http://pubs.usgs. gov/sir/2012/5188.

U.S. Geological Survey, 2013b, Mineral commodity summaries 2013: p. 91

U.S. International Trade Commission, 2013, International tariff and trade dataweb, accessed May 13, 2013, at http:// dataweb.usitc.gov/.

Wilburn, D.R., and Buckingham, D.A., 2006, Apparent consumption vs. total consumption-A lead-acid battery case study: U.S. Geological Survey Scientific Investigations Report 2006-5155, 9 p., accessed June 13, 2013, at http:// pubs.usgs.gov/sir/2006/5155/.

Prepared by the Columbus, Tacoma, Pembroke, and Reston Publishing Service Centers

For more information concerning this report, contact:

Donald I. Bleiwas

Physical Scientist

Global Mineral Analysis Section

National Minerals Information Center, U.S. Geological Survey

bleiwas@usgs.gov 


\section{$\frac{\mathbb{3}}{\mathbb{3}}$}

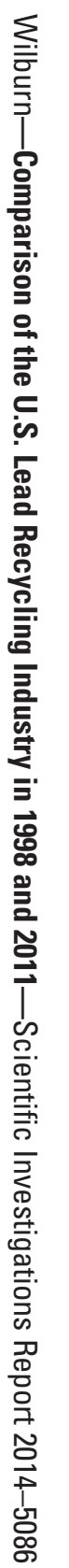

